\title{
Effect of Experimental Parameters on Wear Response of Thermally Sprayed Carbide Based Coatings
}

\author{
Nitesh Vashishtha ${ }^{a *}$, Sanjay Sapate ${ }^{a}$ \\ ${ }^{a}$ Department of Metallurgical and Materials Engineering, Visvesvaraya National Institute of Technology (VNIT), \\ South Ambazari Road, Nagpur, India
}

Received: July 06, 2018; Revised: September 24, 2018; Accepted: October 03, 2018

\begin{abstract}
Friction and abrasive wear response of WC- $12 \mathrm{Co}$ and $\mathrm{Cr}_{3} \mathrm{C}_{2}-25 \mathrm{NiCr}$ coatings was studied. Abrasive wear experiments were conducted with $\mathrm{SiC}$ abrasive particles with varying load and sliding speeds. The results were analyzed using SEM, XRD and XPS observations of worn surfaces, wear debris and worn out abrasive paper. Friction coefficient diminished with rise in sliding speed and increased for increase in load while wear rates decreased for increasing sliding speed for both coatings. WC-12 Co coating had better wear resistance than $\mathrm{Cr}_{3} \mathrm{C}_{2}-25 \mathrm{NiCr}$ coating while $\mathrm{Cr}_{3} \mathrm{C}_{2}-25 \mathrm{NiCr}$ coating displayed lower friction coefficient. The variation in wear rate and friction response of coatings was due to combined effects of adhesion, abrasion and tribo oxidation effects. The composition of tribo films was strongly influenced by load and sliding velocity and altered friction and wear response of the coatings.
\end{abstract}

Keywords: Thermal spray coating, abrasion, particle size, fracture.

\section{Introduction}

Thermally sprayed cermet coatings based on hard carbide phases like $\mathrm{WC}$, and $\mathrm{Cr}_{3} \mathrm{C}_{2}$ are increasingly used for mitigation against high temperature, wear and corrosion to increase life of engineering components. High Velocity Oxy Fuel (HVOF) sprayed WC-Co and $\mathrm{Cr}_{3} \mathrm{C}_{2}-\mathrm{NiCr}$ coatings are suitable for different wear conditions due to higher hardness and good toughness. The major applications of carbide based coatings are in automobile, aerospace, power generation, hydraulic, steel, mining and paper industries. Typical abrasive wear applications include landing gears of aircrafts, fans used in cement industries, sand pumps and tool bits etc. ${ }^{1-9}$. Coating composition, microstructure and mechanical properties are crucial factors influencing their tribological behaviour.

Carbide dissolution and formation of brittle carbides during thermal spraying process had significant influence on wear tribological behaviour of coatings ${ }^{1,10-14}$. HVOF process is the best method to deposit WC-Co and $\mathrm{Cr}_{3} \mathrm{C}_{2}-\mathrm{NiCr}$ type coatings as compared to other thermally sprayed techniques (e.g. plasma spray, detonation gun, flame spray etc.) ${ }^{15-19}$. High particle velocity and low flame temperature in $\mathrm{HVOF}$ process leads to low decomposition of $\mathrm{WC}$ and $\mathrm{Cr}_{3} \mathrm{C}_{2}$ particles, which has been reported beneficial for wear resistance of WC-Co and $\mathrm{Cr}_{3} \mathrm{C}_{2}-$ $\mathrm{NiCr}$ coatings ${ }^{16,20,21}$. The initial coating powder morphology, carbide particle size, volume fraction of carbide, binder phase and coating spray parameters (e.g. velocity, temperature, pressure, fuel type) affect structure and properties of the coating 4,5,20,22-28 . WC-17Co coatings with fine carbide grain size distribution had lower abrasive wear resistance due to more decomposition of $\mathrm{WC}$ into $\mathrm{W}_{2} \mathrm{C}$ which is detrimental for abrasive wear resistance, as reported earlier ${ }^{24}$. Yang et al. reported that wear rate was more sensitive to carbide size rather than the hardness and toughness of the coating ${ }^{29} \cdot \mathrm{Cr}_{3} \mathrm{C}_{2}-\mathrm{NiCr}$ coating having nano crystalline grains (CNG) exhibited lower friction coefficient around than conventional grains coating (CGC) which was due to different material removal mechanisms ${ }^{30}$.

The assessment of performance of thermally sprayed coatings is complicated due to different response shown by hard particles and soft matrix phase, under wear situations involving solid particles ${ }^{31}$. The important factors which influence abrasive wear behaviour of carbide based coatings are carbide particle size, hardness of carbide phase, nature of binder apart from abrasive particle properties; size, shape and hardness. The important abrasive wear mechanisms in $\mathrm{WC}$ and $\mathrm{Cr}_{3} \mathrm{C}_{2}$ based coatings involve fatigue, binder extrusion, carbide pull out, carbide fracture, intergranular cracking and splat fracture severity of which depends on abrasive wear situations ${ }^{9,19,32,33}$. Tribo film formation during abrasive wear process also alters wear and friction response of thermally sprayed cermet coating as influenced by sliding speed, load, nature, composition and thermodynamic stability of oxides ${ }^{19,34,35}$. The formation of $\mathrm{WO}_{3}$, dense $\mathrm{CoWO}_{4}$ tribo films due to tribo oxidation phenomenon helped in reducing friction coefficient and wear rate of WC-Co coating, whereas spinel phase $\mathrm{NiCrO}_{4}$ formation in abrasive wear of $\mathrm{Cr}_{3} \mathrm{C}_{2}-\mathrm{NiCr}$ coatings resulted in improved friction and wear response ${ }^{19,35}$. Mohanty et al. found that friction coefficient showed decreased for increasing sliding velocity in case of $\mathrm{Cr}_{3} \mathrm{C}_{2}-\mathrm{NiCr}$ coating ${ }^{36}$. Wear rate and coefficient of friction (COF) for carbide based coatings reduced for increasing sliding speed while effect of load on $\mathrm{COF}$ and wear rate depends upon coating composition, wear mode and wear test parameters ${ }^{19,35,37-39}$. 
Abrasive wear rate increased with abrasive particle size up to a critical particle size of $100-150 \mu \mathrm{m}$ and then remained more or less constant ${ }^{40-42}$. The wear and friction behaviour of stainless steel, ferritic and martensitic steel was explained in terms of particle size effect; i.e., clogging, capping, attrition and shelling of abrasive particle during abrasive wear ${ }^{43-45}$. The increased wear rate of WC-Co -Cr coating with increasing abrasive size was due to change in wear mechanism from plastic grooving to fracture ${ }^{5}$. Using factorial design approach it was concluded that effect of load rather than abrasive size on wear rate of Co-CrC coating was dominating ${ }^{8}$. Pirso et al. found that abrasive wear performance of TiC-NiMo and $\mathrm{Cr}_{3} \mathrm{C}_{2}-\mathrm{Ni}$ coatings was inferior to WC-Co coating due to different binder hardness and its effect on wear mechanisms ${ }^{46}$. TiC-Ni based coating showed increased abrasive wear loss of around seven times for increase in abrasive size from $30 \mu \mathrm{m}$ to $200 \mu \mathrm{m}^{47}$.

In the previous study ${ }^{19}$, friction and wear behaviour of WC-12 Co and $\mathrm{Cr}_{3} \mathrm{C}_{2}-25 \mathrm{NiCr}$ coatings were studied with $150 \mu \mathrm{m} \mathrm{SiC} \mathrm{particles,} \mathrm{in} \mathrm{which} \mathrm{friction} \mathrm{behaviour} \mathrm{of}$ coating was predominantly influenced by abrasion. The particle size effect is established in the literature however, the effect of tribo oxidation in modifying adhesion and abrasion component of friction with decrease in abrasive particles size has not been studied previously. This has been the impetus for the present investigation. The present work is aimed at studying abrasive wear and friction and response of WC-12 Co and $\mathrm{Cr}_{3} \mathrm{C}_{2}-25 \mathrm{NiCr}$ coatings for different loads and sliding speeds using $50 \mu \mathrm{m} \mathrm{SiC}$ particles. The Tribo oxidation effects were analyzed comprehensively. SEM, XRD and XPS analyses of worn surfaces provided an insight into tribo mechanisms and formation of tribo chemical reaction films.

\section{Experimental Procedure}

\subsection{Coating powders, deposition and Characterisation}

Two commercial powders WC-12\%Co (WOKA 3102) and $\mathrm{Cr}_{3} \mathrm{C}_{2}-25 \% \mathrm{NiCr}$ (WOKA 7202) manufactured by sintering and agglomeration route by Sulzer Metco, Germany were used in this study. The powders were in size range of - 45 $\mu \mathrm{m}+15 \mu \mathrm{m}$ with spherical shape. Both the coatings were deposited on 316 stainless steel substrate. The coating deposition parameters, substrate preparation and other details regarding structural characterization and mechanical property measurement are described in previous publication ${ }^{9,19}$.

\subsection{Wear experiments}

Wear testing was performed using Pin on Disc setup with $\mathrm{SiC}(50 \mu \mathrm{m})$ abrasive paper, at room temperature. Wear test conditions were; $15,30,45$, and $60 \mathrm{~N}$ load with sliding speeds of $0.25,0.5,1.0$ and $1.5 \mathrm{~m} \mathrm{~s}^{-1}$ and sliding distance was $1271 \mathrm{~m}$. The specimens were in cylindrical form of $25 \mathrm{~mm}$ length and diameter $10 \mathrm{~mm}$. The details regarding specimen preparation for wear testing and method of wear testing is detailed in previous publication ${ }^{19}$. Frictional force during abrasive wear testing was continuously recorded to determine coefficient of friction (COF). The morphology of worn surfaces and wear debris was examined and analyzed by using SEM, EDS, XRD and XPS. Carbon peak corresponding to $284.6 \mathrm{eV}$ binding energy was used as the reference. XPS peak 4.1 software was used to fit XPS peaks. The binding energies of various phases were revealed by Standard Reference Database 20, (NIST), Version 4.1.

\section{Results}

\subsection{Properties of coatings}

Fig. $1 \mathrm{a}$ and $1 \mathrm{~b}$ shows the lamellar microstructure of WC-12 Co and $\mathrm{Cr}_{3} \mathrm{C}_{2}-25 \mathrm{NiCr}$ coatings, respectively. WC and $\mathrm{Cr}_{3} \mathrm{C}_{2}$ particles were uniformly disperse in cobalt and nickel-chrome binder, respectively in $\mathrm{WC}-12 \mathrm{Co}$ and $\mathrm{Cr}_{3} \mathrm{C}_{2}-25 \mathrm{NiCr}$ coatings were forming a dense coating structure with lower porosity. EDS spectra revealed the $\mathrm{W}$, Co were the main elements in WC-12Co coating (Fig. 1c) while $\mathrm{Cr}$, Ni were the main element in $\mathrm{Cr}_{3} \mathrm{C}_{2}-25 \mathrm{NiCr}$ coating (Fig. 1d). WC particles (bright regions) were surrounded by Co binder in WC-12Co coating (Fig. 1a). In $\mathrm{Cr}_{3} \mathrm{C}_{2}-25 \mathrm{NiCr}$ coating, $\mathrm{Cr}_{3} \mathrm{C}_{2}$ particle observed as grey regions which were surrounded by dark grey $\mathrm{NiCr}$ binder (Fig. 1b). No microcracking was seen on the both coating surfaces. Cross-sectional micrographs were used for measuring porosity, carbide size by image analysis. The average size of $\mathrm{WC}$ and $\mathrm{Cr}_{3} \mathrm{C}_{2}$ particle size was 1.5 $\pm 0.5 \mu \mathrm{m}$ and $2.5 \pm 0.5 \mu \mathrm{m}$, respectively. The calculated area percentage porosity was $1.2 \%$ and $1.5 \%$ for $\mathrm{WC}-12$ $\mathrm{Co}$ and $\mathrm{Cr}_{3} \mathrm{C}_{2}-25 \mathrm{NiCr}$ coatings, respectively. WC-12Co coating showed higher microhardness $(1270 \pm 100 \mathrm{HV})$ than $\mathrm{Cr}_{3} \mathrm{C}_{2}-25 \mathrm{NiCr}$ coating $(825 \pm 80 \mathrm{HV})$. The indentation fracture toughness measured on cross-section was $4.5 \pm$ 1.0 M Pa $\sqrt{\mathrm{m}}$ and $3.7 \pm 0.9 \mathrm{M} \mathrm{Pa} \sqrt{\mathrm{m}}$ for $\mathrm{WC}-12 \mathrm{Co}$ and $\mathrm{Cr}_{3} \mathrm{C}_{2}-25 \mathrm{NiCr}$ coatings, respectively ${ }^{9}$.

\section{$3.2 \mathrm{COF}$ and wear rate}

Typical coefficient of friction curves of both the coatings at different sliding speeds $\left(0.25-1.5 \mathrm{~m} \mathrm{~s}^{-1}\right.$ and load (15-60 N) are shown in Fig. 2(a-d). In the running in period, COFs increased initially then decreased and then increased to reach a steady state region, after sliding distance of 400-500 meters. Initially the contact between the coating surface and abrasive particle occur at a few asperities, which results in increased contact stress at the asperity junction. When wear proceeds further, real contact area increased leading to reduction in stress at 

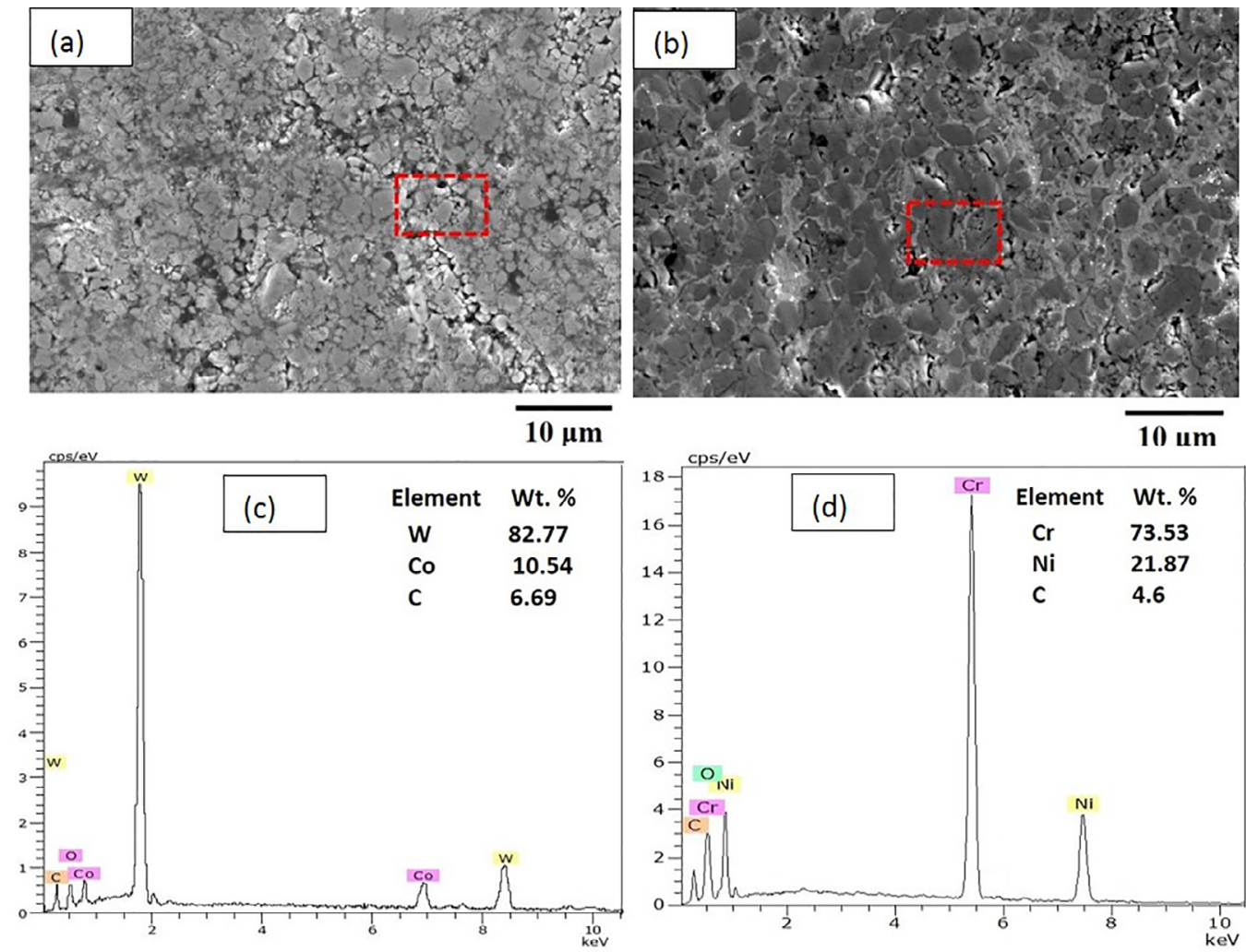

Figure 1. SEM micrographs of microstructure of coatings (a) WC-12Co (b) $\mathrm{Cr}_{3} \mathrm{C}_{2}-25 \mathrm{NiCr}$ and EDS analysis of coatings (c) $\mathrm{WC}-12 \mathrm{Co}(\mathrm{d}) \mathrm{Cr}_{3} \mathrm{C}_{2}-25 \mathrm{NiCr}$.
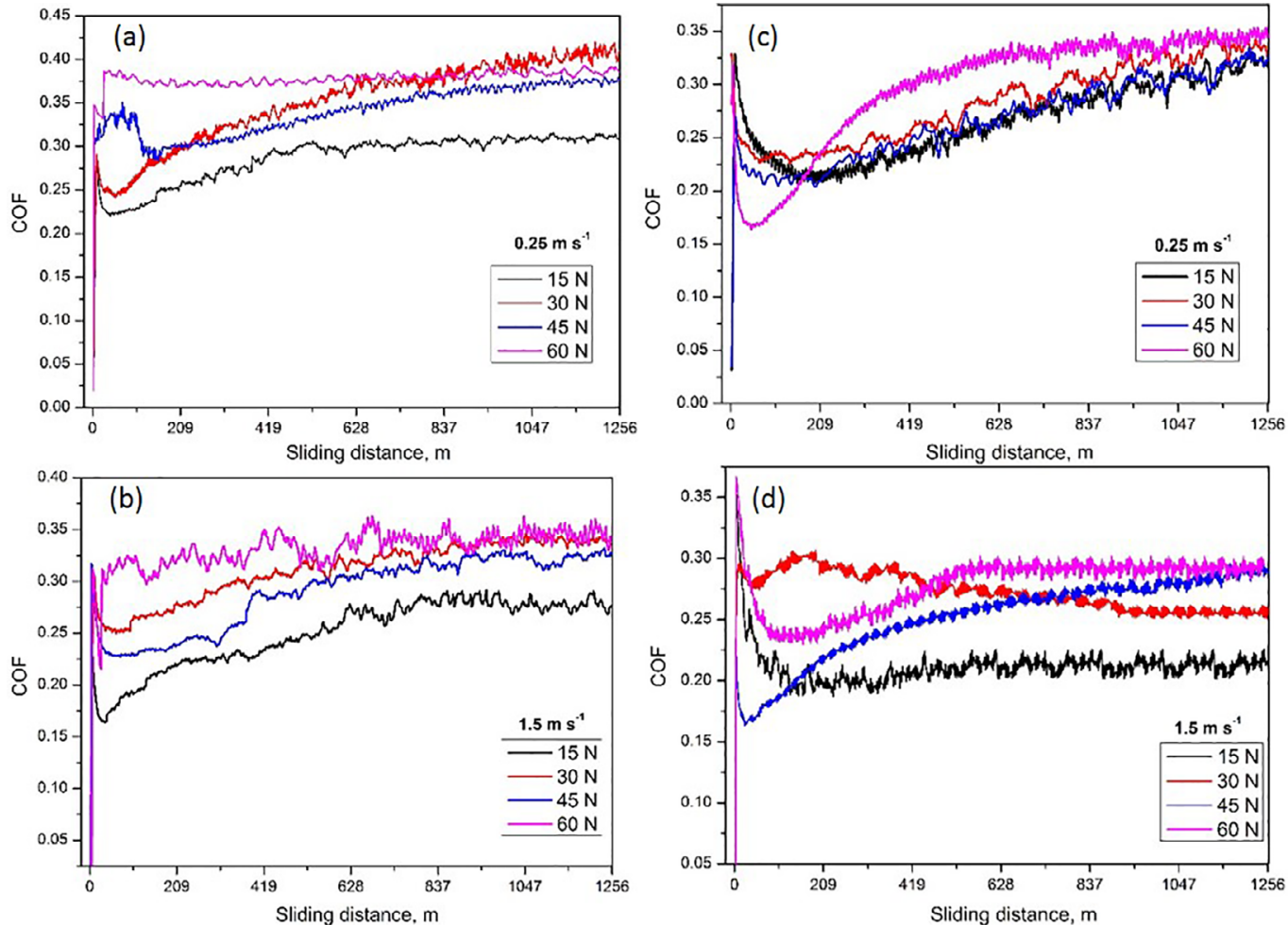

Figure 2. COF curve variations under different abrasive wear conditions for (a,b) WC-12Co coating and (c,d) $\mathrm{Cr}_{3} \mathrm{C}_{2}-25 \mathrm{NiCr}$ coating. 
the asperity junction and COF. With further sliding, wear debris generated due to plastic deformation covers the coating surface, causing an increase in adhesion, resulting in rise in friction force and COF. The fluctuations in COF curve can be attributed to formation and delamination of tribolayer and formation of tribo chemical reaction films on the worn surface, which is discussed in section 4. With increasing sliding distance more and more wear debris is generated due to plastic deformation and fracture depending upon load. Similarly, more and more abrasive particle fracture and fragmentation occur with increase in sliding distance and load. With increasing sliding speed and load both oxidative wear and mechanical wear prevail leading to removal of tribo oxide film by delamination cracking and fracture which generates oxide debris. The wear debris, fractured abrasive particles and oxide debris results in material removal by three body abrasion and tend to increase friction force and COF with increasing sliding distance particularly at higher loads, which is discussed in detail in section 4.

COF values were plotted vs. load and sliding velocities for both coatings, as displayed in Fig. 3(a-d), respectively. Friction coefficients for WC-12 Co coating
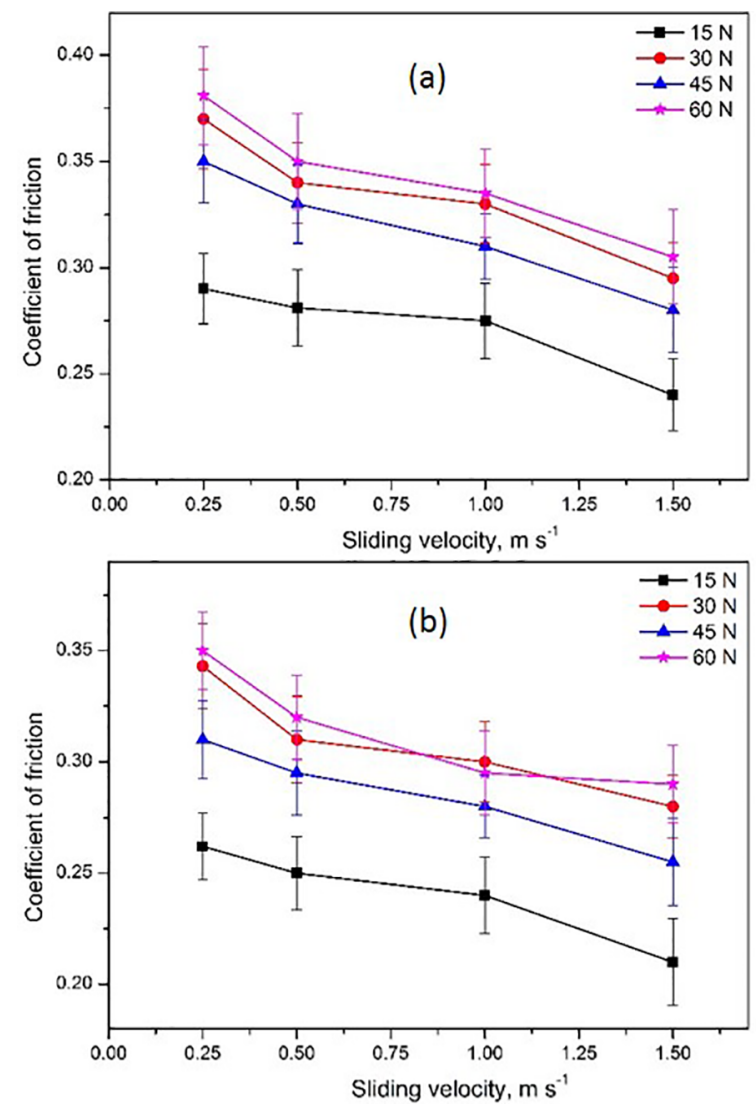

Figure 3. $\mathrm{COF}$ vs. sliding velocity plots of coatings (a) $\mathrm{WC}-12 \mathrm{Co}$ (d) $\mathrm{Cr}_{3} \mathrm{C}_{2}-25 \mathrm{NiCr}$. were observed to be $0.29-0.38,0.28-0.35,0.27-0.33$ and $0.24-0.30$ for velocities of $0.25,0.5,1.0$ and $1.5 \mathrm{~m}$ $\mathrm{s}^{-1}$, and for load range of $15-60 \mathrm{~N}$, respectively. While the respective COF values were 0.26-0.35, 0.25-0.32, 0.24-0.29 and 0.21-0.28 for $\mathrm{Cr}_{3} \mathrm{C}_{2}-25 \mathrm{NiCr}$ coating. $\mathrm{COF}$ showed decreasing trend with increasing sliding speed $\left(0.25-1.5 \mathrm{~m} \mathrm{~s}^{-1}\right)$, for both the coatings. For both coatings, lowest friction coefficient was noted at $1.5 \mathrm{~m} \mathrm{~s}^{-1}$ velocity, irrespective of the load. It was seen from graphs that the decrease in COF was not more than $20 \%$ for increase in sliding speed, for both coatings. For both coatings, COF displayed an increasing trend, for entire range of sliding speeds with an increase in load from 15 to $30 \mathrm{~N}$ followed by a decrease to $45 \mathrm{~N}$ and further increased when the load is reached to $60 \mathrm{~N}$. It can be noted that COF values at 30 $\mathrm{N}$ and $60 \mathrm{~N}$ were nearly similar or slightly higher at 60 $\mathrm{N}$, as shown in Fig. 3(c-d). The rise in COF was in the range of 21-31\% in case of WC-12 Co coating while for $\mathrm{Cr}_{3} \mathrm{C}_{2}-25 \mathrm{NiCr}$ coating, the increase in COF was 23-34 $\%$ when the load is increased from 15-60 N. Fig. 2 also showed that depending on sliding speed and load, $\mathrm{COF}$ values were $7-15 \%$ lower for $\mathrm{Cr}_{3} \mathrm{C}_{2}-25 \mathrm{NiCr}$ coating than WC-12 Co coating.
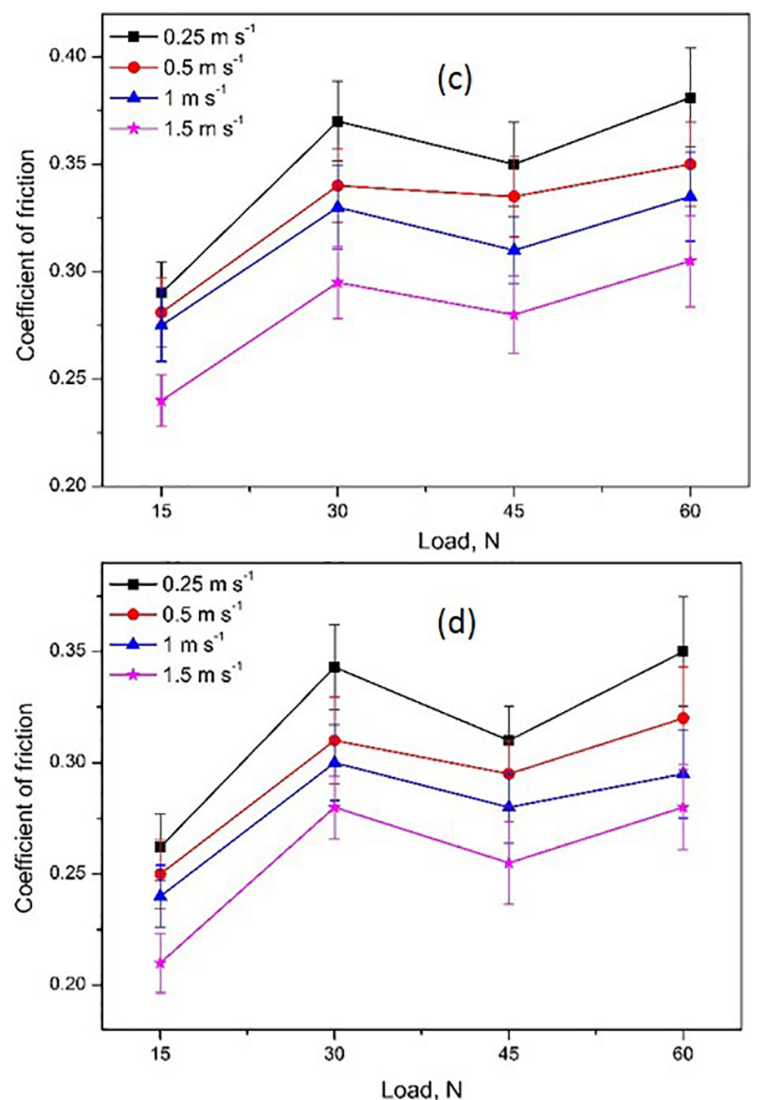

Load, $N$ 
The wear rates for change in load and sliding speed for coatings are displayed in Fig. 4(a-d). Wear rate of both coatings showed decreasing trend for increase in sliding velocity $\left(0.25\right.$ to $\left.1.5 \mathrm{~m} \mathrm{~s}^{-1}\right)$. With WC-12 Co coating, the wear rates diminished by $31-42 \%$ while this decrease was in the range of $22-36 \%$ for $\mathrm{Cr}_{3} \mathrm{C}_{2}-25 \mathrm{NiCr}$ coating within $15-60 \mathrm{~N}$ load range. Within the load range of $15-60 \mathrm{~N}$ load, increase in wear rate was $2.68,2.79,2.63$ and 2.72 times for sliding velocities of $0.25,0.5,1.0$ and $1.5 \mathrm{~m} \mathrm{~s}^{-1}$, respectively for WC-12 Co coating while corresponding increase was $3.09,3.42,2.74$ and 2.58 times for $\mathrm{Cr}_{3} \mathrm{C}_{2}-25 \mathrm{NiCr}$ coating. $\mathrm{Cr}_{3} \mathrm{C}_{2}-25 \mathrm{NiCr}$ coating showed 2.2-2.8 times higher abrasive wear rates, than WC-12 Co coating, within the range of load and sliding speed.

\subsection{Wear mechanisms}

SEM micrographs of worn surfaces for both the coatings, at different sliding speeds and loads are shown in Figs. 5(a-h) and 6(a-h), respectively. From the worn surfaces it was observed that the severity of abrasion increased for rise in load from 15 to $60 \mathrm{~N}$. At lower sliding speeds of less than $1 \mathrm{~m} \mathrm{~s}^{-1}\left(0.25-0.5 \mathrm{~m} \mathrm{~s}^{-1}\right)$ and up to load of $30 \mathrm{~N}$ for WC-12Co coating, the abrasive wear mechanism involved displacement of carbide grains, plastic grooving and binder extrusion, which can be seen in Fig. 5a. Compressive stresses exerted by hard abrasive $\mathrm{SiC}$ particles results in binder extrusion and removal of cobalt binder phase, which leads to loss in mechanical strength and subsequent decrease in the support to WC carbide. This resulted in displacement of mechanically loosed WC particles and their bodily removal from the coating matrix by the action of repeated cyclic fatigue with increasing load ${ }^{9,33}$. At 45-60 N load, rise in wear rates were associated with increased depth of grooving, fracture of carbides, carbide pull out and inter granular cracking as seen in Fig. 5(b-c). The propensity of carbide pull out increased with load, as fractured abrasive particle can effectively undermine the binder phase. The material removal mechanisms from the $\mathrm{Cr}_{3} \mathrm{C}_{2}-25 \mathrm{NiCr}$ coating under abrasive wear conditions were similar to the WC-12Co coating. In $\mathrm{Cr}_{3} \mathrm{C}_{2}-25 \mathrm{NiCr}$ coating relatively high percentage of binder content resulted in more binder phase extrusion, which can be seen in Fig. 6(a) at $30 \mathrm{~N}$ load and $0.25 \mathrm{~m} \mathrm{~s}^{-1}$ sliding speed. At higher loads, worn surface showed fracture and pull out of carbide grains (Fig. 6b-c). Carbide pull out, inter granular cracking and inter splat fracture leads to higher abrasive rates ${ }^{11,19}$.
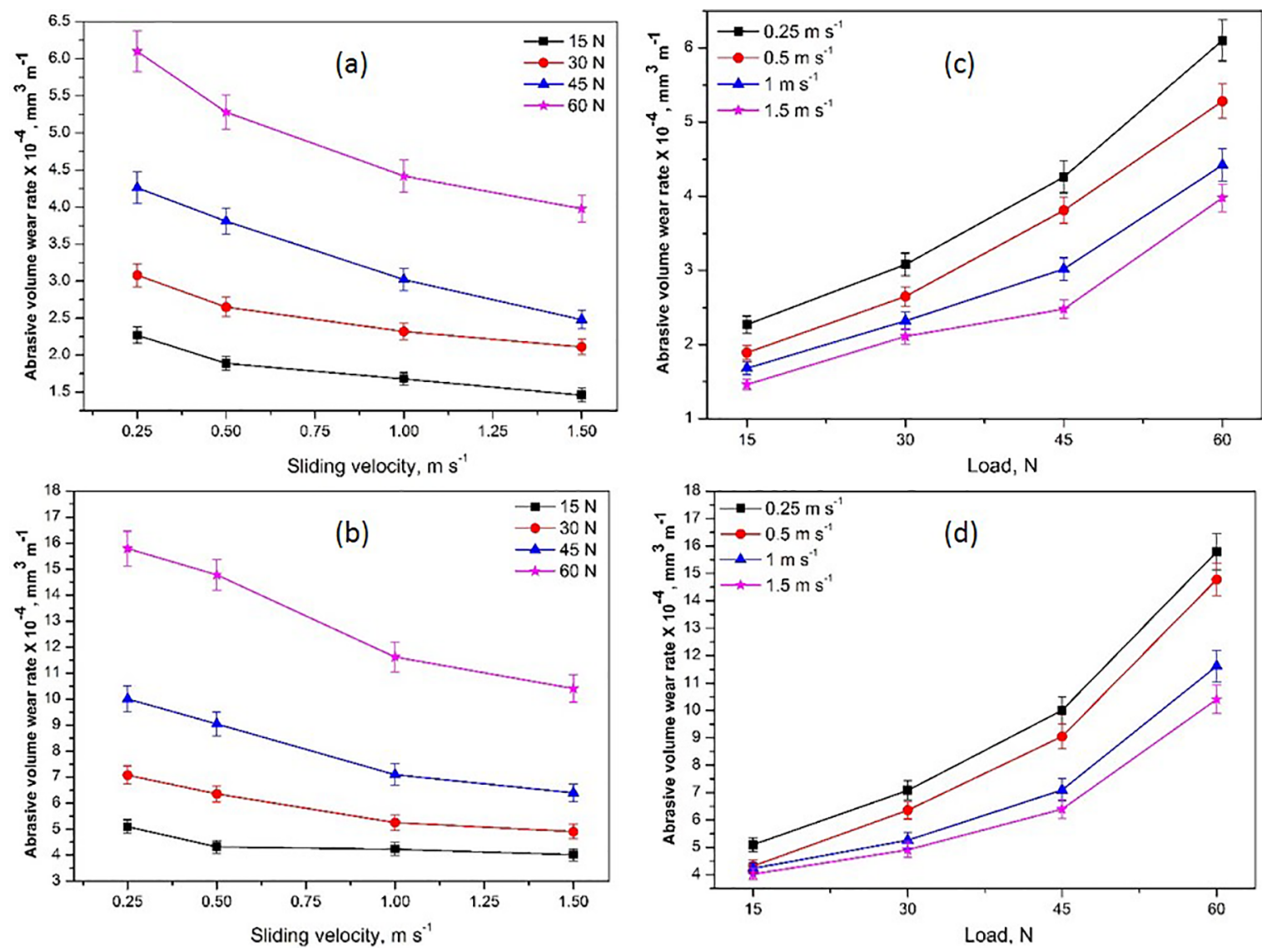

Figure 4. Abrasive wear rate vs. sliding velocity of coatings (a) $\mathrm{WC}-12 \mathrm{Co}$ (b) $\mathrm{Cr}_{3} \mathrm{C}_{2}-25 \mathrm{NiCr}$ and abrasive wear rate vs. load of coatings (c) $\mathrm{WC}-12 \mathrm{Co}$ (d) $\mathrm{Cr}_{3} \mathrm{C}_{2}-25 \mathrm{NiCr}$. 

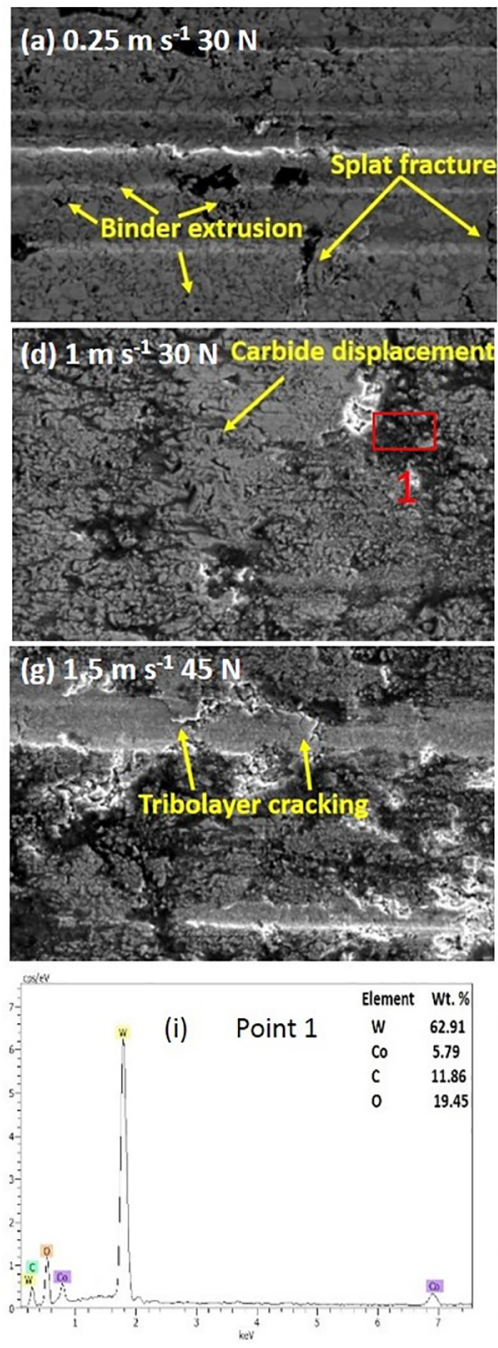
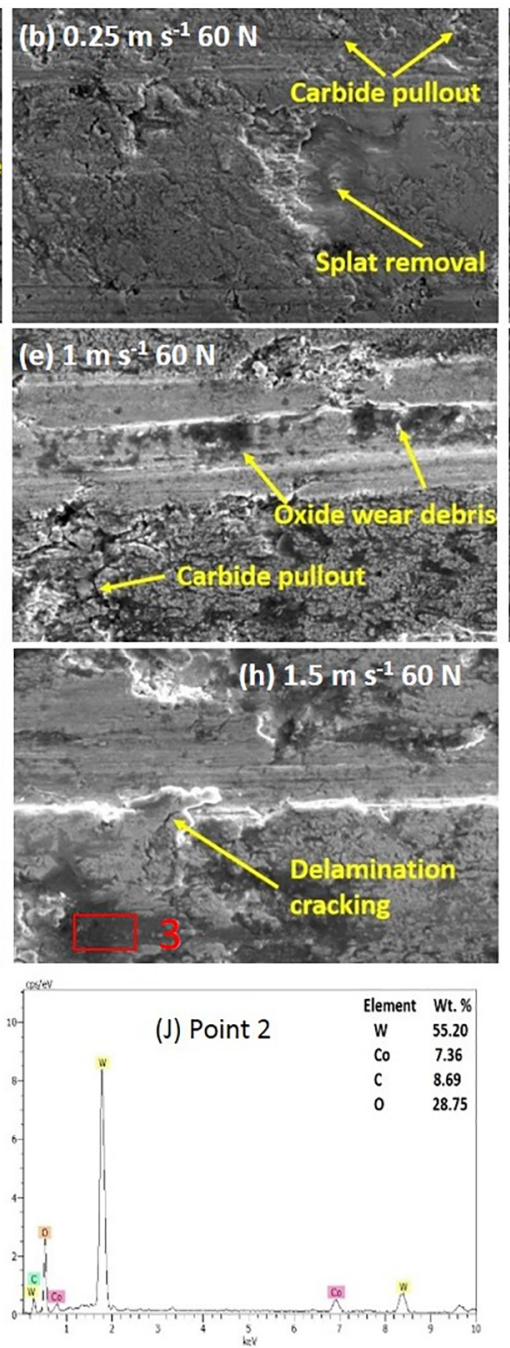
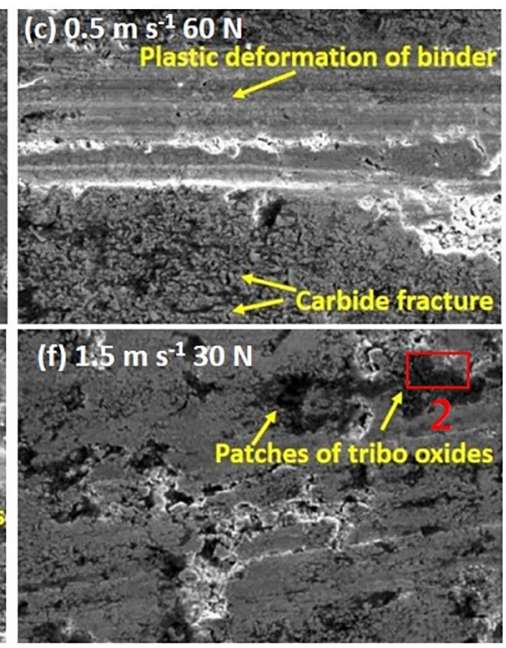

$\overline{10 \mu \mathrm{m}}$

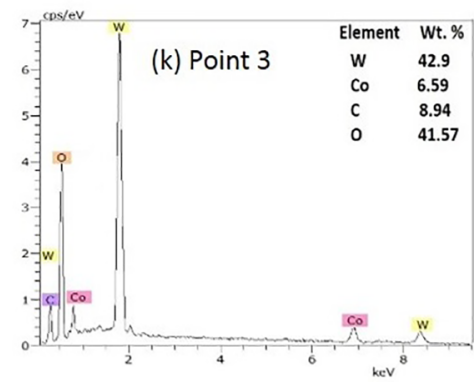

Figure 5. (a-h) SEM micrographs of worn out surafces of WC-12Co coating at different abrasive wear conditions. EDS analysis of selected points (i-k).

$\mathrm{Cr}_{3} \mathrm{C}_{2}-25 \mathrm{NiCr}$ coating showed higher abrasive rates than WC-12 Co coating, which were due to lower fracture toughness of $\mathrm{Cr}_{3} \mathrm{C}_{2}-25 \mathrm{NiCr}$ coating than WC-12 Co coating ${ }^{9}$. With rise in sliding speed, oxidative wear mechanism also played an important role in altering friction and wear response of coatings. As the sliding velocity is increased from $0.25-1.5$ $\mathrm{m} \mathrm{s}^{-1}$, the propensity of tribo oxidation increased which is evident from morphology worn surfaces of both coatings, as shown in Fig. 5(c-h) and 6(c-h). During wear, some of the debris particle get swept away while some retained in wear tracks are subjected to oxidation due to frictional heating. The fragmentation, oxidation, agglomeration and subsequent compaction forms a tribo-film separating contact between the abrasive particles and the worn surface and prevents further damage, as summarized previously ${ }^{19}$.

As the flash temperature is increased, the adhesive forces between individual oxide wear debris became stronger and enhances the compaction of tribo film to the coating surface.
This tribo layer having lower shear strength serves as solid lubricant and prevents further damage to the worn surface reducing not only wear rate but also COF ${ }^{19,34,48}$. At higher sliding velocity of 1.0 and $1.5 \mathrm{~m} \mathrm{~s}^{-1}$, intense frictional heating caused oxidation of worn surface and resulted in covering of worn surface with tribo film (Fig. 5d-h and 6d-h). Wear tracks filled with oxide debris and number of hot spot patches confirming the localized heating, which can be observed in Fig. 5e-h and 6e-h. tribo film effectiveness in reduction of $\mathrm{COF}$ and wear rate is affected by its thermodynamic stability, adherence with the substrate, nature and its composition 19,49. The tribo film is expected to be removed by shearing process at lower loads rather than by delamination cracking at higher loads as shown in Fig. 5(e,g,h) and Fig. 6(e,g,h), which also indicates fractured tribo film. With the removal of tribo film the contact conditions are modified, fresh contact occur between abrasive particle and the surface, and wear rate increases at higher loads. The extent of tribo-oxidation 

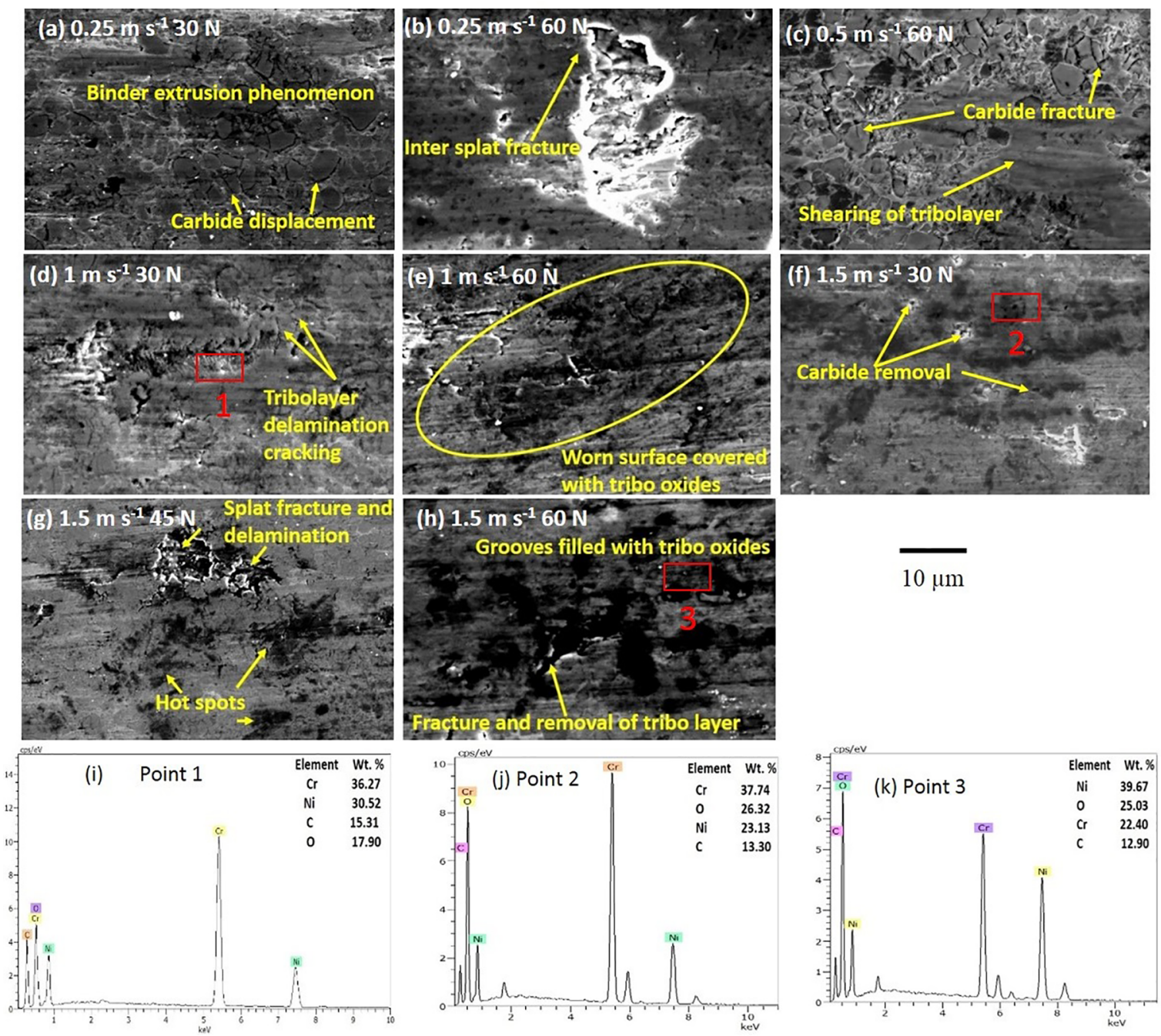

Figure 6. (a-h) SEM micrographs of worn out surafces of $\mathrm{Cr}_{3} \mathrm{C}_{2}-25 \mathrm{NiCr}$ coating at different abrasive wear conditions. EDS analysis of selected points (i-k)

with varying sliding speed and load and can be assessed by rise in flash temperature, EDS, XRD, XPS analyses of worn surface, which is discussed in subsequent sections.

Frictional heat developed during abrasive wear leads to rise in flash temperature, at real contact area, which accelerates tribo-oxidation reactions resulting in tribo-oxide film formation. The increase in flash temperature with varying load and sliding speed provides useful information which can be used to predict different oxidation regimes from mild to severe. The increase in localized temperature at asperities junctions, i.e. flash temperature, was calculated as per equation $1^{50,51}$,

$$
\begin{aligned}
& \Delta T=\frac{\mu P V}{4 J(K a+K \text { coat }) a} \\
& \text { Where, } a=\left(\frac{P}{\pi \text { Hcoat }}\right)^{1 / 2}
\end{aligned}
$$

where, $\Delta \mathrm{T}=$ increase in flash temperature $\left({ }^{\circ} \mathrm{C}\right), \mathrm{P}=$ test $\operatorname{load}(\mathrm{N}), \mu=$ frictional coefficient, $\mathrm{V}=\operatorname{sliding} \operatorname{speed}\left(\mathrm{m} \mathrm{s}^{-1}\right)$, $\mathrm{J}=$ Joule's constant (1), $\mathrm{K}_{\text {coat }}$ and $\mathrm{Ka}$ are thermal conductivity of coating and $\mathrm{SiC}$ abrasive, $\mathrm{a}=$ real area of contact $(\mathrm{m}), \mathrm{H}_{\text {coat }}$ = coating hardness $\left(\mathrm{N} \mathrm{m}^{-2}\right)$.

Flash temperatures increased for increase in both, load $(15-60 \mathrm{~N})$ and speed $\left(0.25-1.5 \mathrm{~m} \mathrm{~s}^{-1}\right)$, as shown in Fig. 7. The calculated flash temperature were in the range of $197-2496^{\circ} \mathrm{C}$ and $179-2306^{\circ} \mathrm{C}$ in case of $\mathrm{WC}-12 \mathrm{Co}$ and $\mathrm{Cr}_{3} \mathrm{C}_{2}-25 \mathrm{NiCr}$ coatings, respectively. It is also noted that rise in flash temperatures were much higher than the actual surface temperature of the coating surface i.e. bulk temperature ${ }^{52}$. The estimated flash temperatures are approximate, because the thermal conductivity of oxide was not taken into account. 


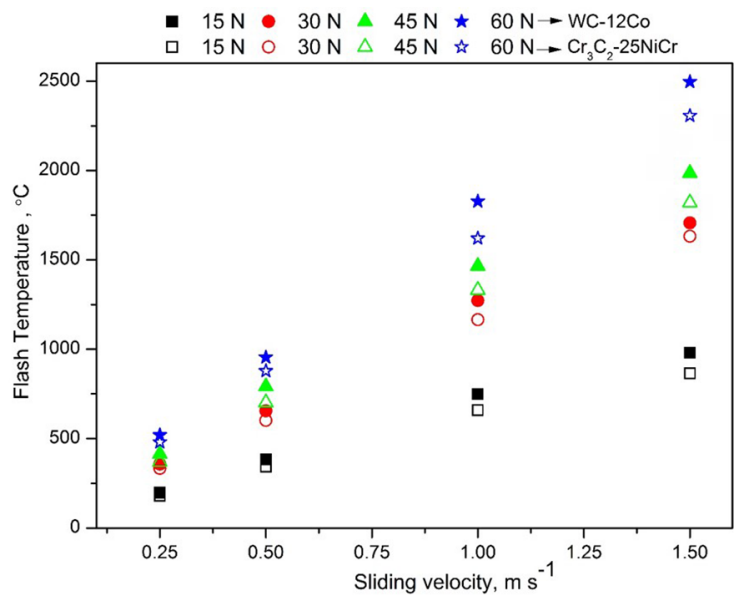

Figure 7. Estimated flash temperatures plots with respect to sliding velocity for both coatings

\subsection{Characterization of worn surface}

EDS spectrum of worn surfaces of WC-12 Co coating showed peaks of oxygen $(\mathrm{O})$ along with tungsten (W)

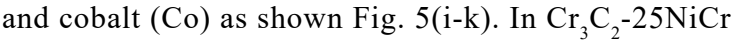
coating, EDS also revealed the peaks of $\mathrm{O}$ along with the chromium $(\mathrm{Cr})$ and nickel (Ni) elements (Fig. 6i-k), suggesting formation of various oxide of $\mathrm{Co}, \mathrm{W}, \mathrm{Cr}$ and $\mathrm{Ni}$. The concentration of oxygen increased for an increase in sliding speed and load, for both coatings, which was in the range of $19-41 \%$ in case of WC-12Co coating while in case of $\mathrm{Cr}_{3} \mathrm{C}_{2}-25 \mathrm{NiCr}$ coating this range was 22-36 $\%$, depending upon the load and sliding velocity, thus suggesting increased tribo oxidation. XRD analyses of worn surface of WC-12Co coating (Fig. 8a-d) showed peaks of tungsten oxides $\left(\mathrm{WO}_{2}, \mathrm{WO}_{3}, \mathrm{~W}_{3} \mathrm{O}_{8}\right)$, cobalt oxides $\left(\mathrm{CoO}, \mathrm{Co}_{3} \mathrm{O}_{4}, \mathrm{CoCo}_{2} \mathrm{O}_{4}\right)$, spinel phase $\mathrm{CoWO}_{4}$ along with peaks of $\mathrm{WC}$ and $\mathrm{Co}$. In case of $\mathrm{Cr}_{3} \mathrm{C}_{2}-25 \mathrm{NiCr}$ coating, peaks of $\mathrm{Cr}_{3} \mathrm{C}_{2}, \mathrm{Cr}_{23} \mathrm{C}_{6}, \mathrm{Cr}_{3} \mathrm{O}, \mathrm{CrO}_{3}, \mathrm{NiO}$ and spinel phase $\mathrm{NiCr}_{2} \mathrm{O}_{4}$ were recorded (Fig. 8e-h). The number of oxide peaks and increased intensity of oxide peaks for rise in both, load and sliding velocity confirmed the prevalence of oxidative wear.

XPS analyses was performed to assess composition of different products of tribo chemical reaction, during abrasive of both the coatings. Fig. 9(a-b) showed XPS surface survey worn surface of both coatings, at $1.5 \mathrm{~m}$ $\mathrm{s}^{-1}$ and $0.25 \mathrm{~m} \mathrm{~s}^{-1}$ velocities at $60 \mathrm{~N}$ load. XPS spectra of W4 $f$ and Co2p of worn surface of WC-Co coating were shown in Fig. 10(a-d). The high resolution spectra of $\mathrm{Cr} 2 \mathrm{p}$ and Ni2p of worn surface of $\mathrm{Cr}_{3} \mathrm{C}_{2}-\mathrm{NiCr}$ coating were displayed in Fig. 10(e-h). The XPS peaks were identified as $\mathrm{WO}_{3}, \mathrm{CoO}$ and $\mathrm{Co}(\mathrm{OH})_{2}$ in case of WC12Co coating and for $\mathrm{Cr}_{3} \mathrm{C}_{2}-\mathrm{NiCr}$ coating, XPS spectra displayed peak of $\mathrm{Cr}_{2} \mathrm{O}_{3}, \mathrm{CrO}_{2}, \mathrm{Cr}(\mathrm{OH})_{2}$ and $\mathrm{NiO}$. The binding energies of various phases is also indicated in XPS spectra.

\section{Discussion}

\subsection{Worn surface analysis}

The occurrence and composition of tribo-oxide and hydroxide films on worn surface of both the coatings, was confirmed by analyses of worn surfaces. At $1.5 \mathrm{~m} \mathrm{~s}^{-1}$ sliding speed, the intensity of $\mathrm{WO}_{3}$ peak was relatively more strong as than that at $0.25 \mathrm{~ms}^{-1}$ sliding speed for WC-12 Co coating surface, as seen in XPS spectra of Fig. 10(a and b). $\mathrm{CoO}$ peaks along with peak of $\mathrm{Co}(\mathrm{OH})_{2}$, due to tribo-chemical reaction with humidity were also recorded at higher sliding speed. It can also be noted that the intensity of $\mathrm{CoO}$ peak was weak at lower speed of $0.25 \mathrm{~m} \mathrm{~s}^{-1}$ and peak of Co with strong intensity were also observed, indicating that temperature rise at lower velocity was not sufficient for oxidation of $\mathrm{Co}$. The tribo oxidation reaction of WC with oxygen can be expressed as per the following equations; 2 and $3^{53}$;

$$
\begin{aligned}
& W C+5 / 2 \mathrm{O}_{2} \rightarrow \mathrm{WO}_{3}+\mathrm{CO}_{2} \\
& \left(\Delta G_{298 K}\right)=-764.12 \text { KJmole }^{-1} \\
& W C+O_{2} \rightarrow W_{2}+C \\
& \left(\Delta G_{298 K}\right)=-533.87 \text { KJmole }^{-1}
\end{aligned}
$$

Where $\Delta \mathrm{G}_{298 \mathrm{~K}}$ is the standard Gibbs free energy of reaction formation.

Magneli phase oxides like, $\mathrm{WO}_{3}$ which has layered structure, helps in decreasing COF depending on whether it is crystalline or amorphous. Spinel phase, $\mathrm{CoWO}_{4}$ was considered beneficial in enhancing wear resistance and reducing $\mathrm{COF}$ due to its high deformity and good lubrication properties ${ }^{35,54-56}$. When $\mathrm{WC}$ reacts with Co binder in presence of environmental oxygen, it results in the formation of $\mathrm{CoWO}_{4}$ phase. The corresponding chemical reaction is given below in equation $4,{ }^{57}$;

$$
\mathrm{Co}+\mathrm{WC}+3 \mathrm{O}_{2} \rightarrow \mathrm{CoWO}_{4}+\mathrm{CO}_{2}
$$

The metastable oxide, $\mathrm{CoO}$ as observed on worn surface aids in reduction of wear rate but $\mathrm{Co}_{3} \mathrm{O}_{4}$ was reported to be more thermodynamically stable than $\mathrm{CoO}$, and effectual to reduction of wear rate and COF. ${ }^{35,58}$. The oxidation of binder Co to $\mathrm{CoO}$ and thereafter further oxidation of $\mathrm{CoO}$ to $\mathrm{Co}_{3} \mathrm{O}_{4}$ can be given in equations 5 and $6^{59}$; as

$$
\begin{gathered}
2 \mathrm{Co}+\mathrm{O}_{2} \rightarrow 2 \mathrm{CoO}\left(\Delta G_{298 K}\right)= \\
-214.22 \mathrm{KJ} \text { mole } \\
3 \mathrm{CoO}+1 / 2 \mathrm{O}_{2} \rightarrow \mathrm{Co}_{3} \mathrm{O}_{4} \\
\left(\Delta G_{298 K}\right)=-794.96 \mathrm{KJ} \mathrm{mole}^{-1}
\end{gathered}
$$



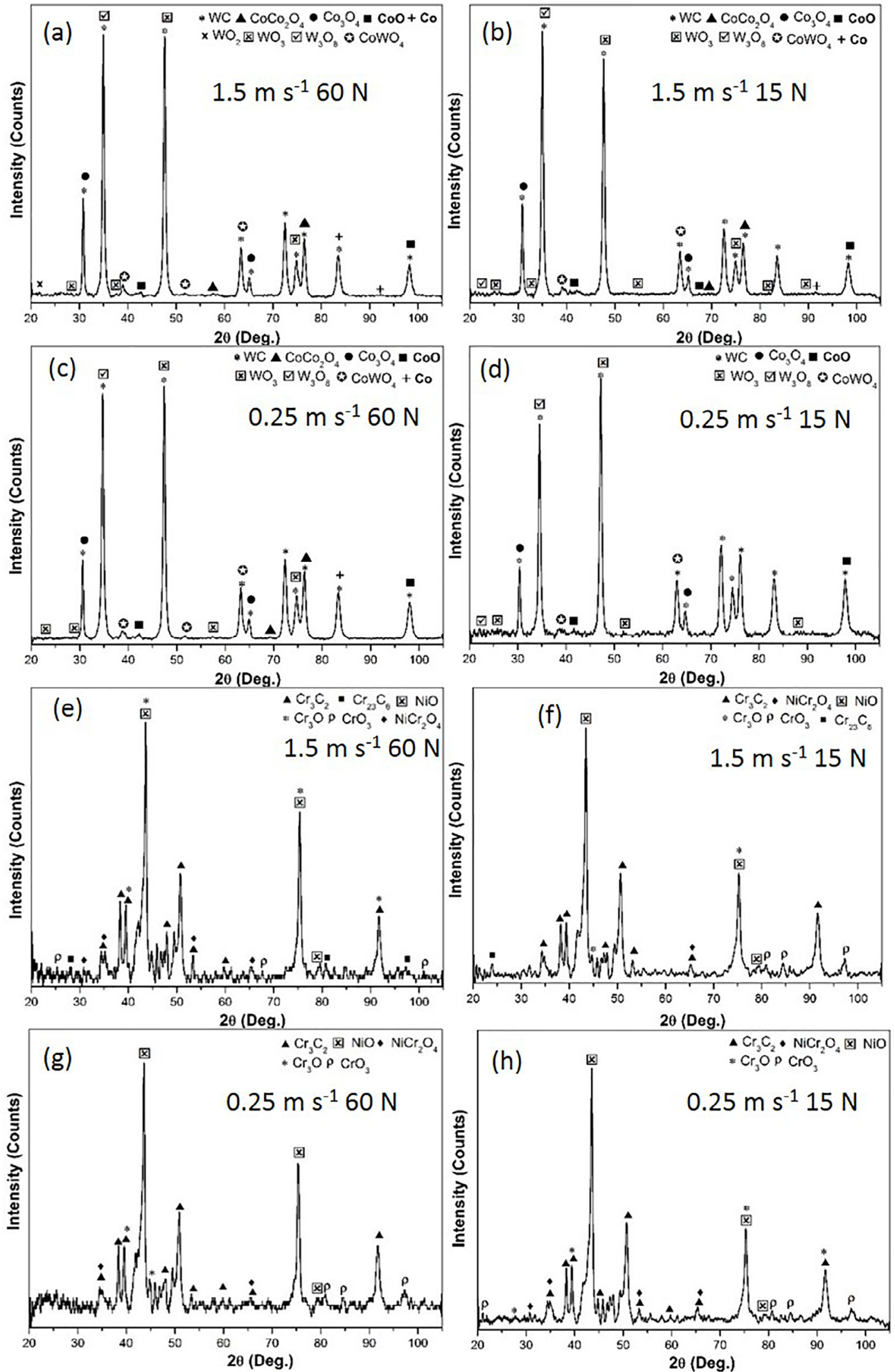

Figure 8. (a-d) XRD spectra of worn out surfaces of WC-12Co coating at different abrasive wear conditions and (e-h) for $\mathrm{Cr}_{3} \mathrm{C}_{2}-25 \mathrm{NiCr}$ coating at different abrasive wear conditions 

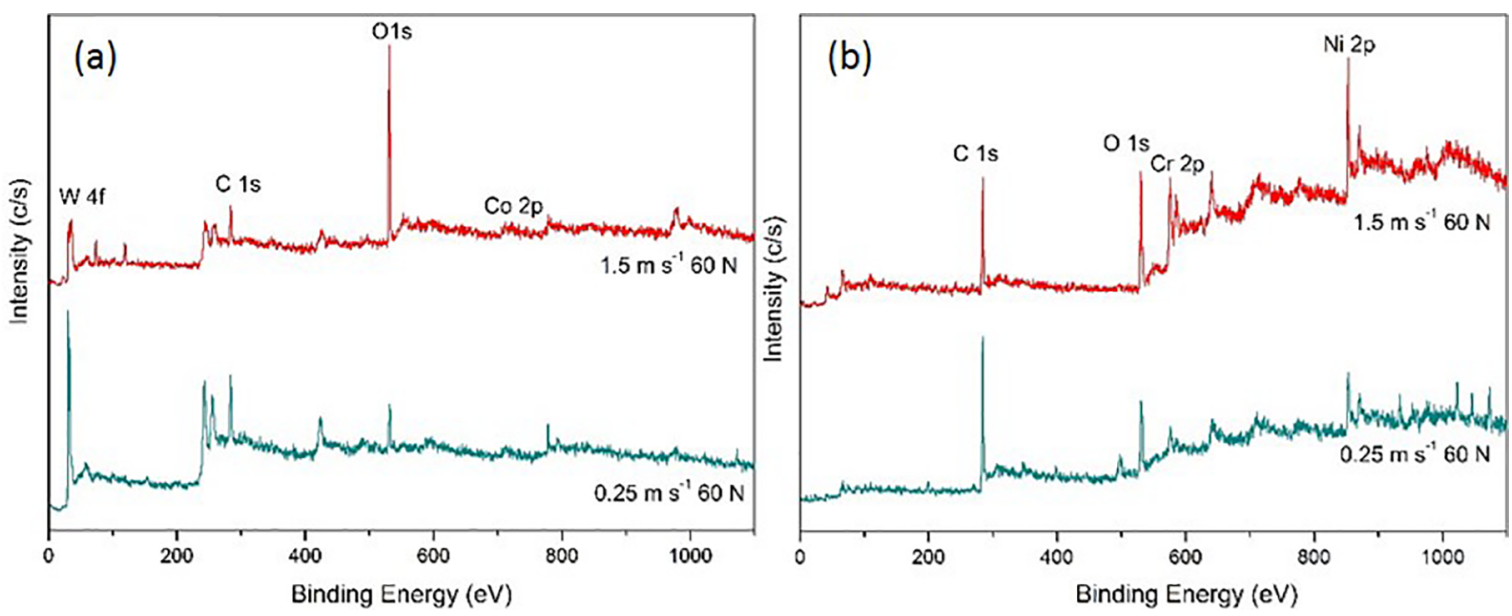

Figure 9. XPS survey spectra of abraded surfaces of coatings (a) WC-12Co (b) $\mathrm{Cr}_{3} \mathrm{C}_{2}-25 \mathrm{NiCr}$

In case of $\mathrm{Cr}_{3} \mathrm{C}_{2}-25 \mathrm{NiCr}$ coating, $\mathrm{Cr}_{2} \mathrm{O}_{3}, \mathrm{CrO}_{3}, \mathrm{CrO}_{2}$ and $\mathrm{NiO}$ were main oxide phases identified by XRD and XPS analyses of worn surface. A strong intensity $\mathrm{Cr}$ and Ni peaks were observed at $0.25 \mathrm{~m} \mathrm{~s}^{-1}$ as compared to that at $1.5 \mathrm{~m} \mathrm{~s}^{-1}$, whereas the intensity of $\mathrm{NiO}$ peak was strong at higher velocity, indicating relatively greater extent of oxidation of binder phase for $\mathrm{Cr}_{3} \mathrm{C}_{2}-25 \mathrm{NiCr}$ coating, at higher velocity (Fig. 10e-h). $\mathrm{Cr}_{2} \mathrm{O}_{3}$ film with more passivity and lower negative Gibbs free energy, indicates beneficial effect of $\mathrm{Cr}_{2} \mathrm{O}_{3}$ film in decrease of wear rate and COF than $\mathrm{CrO}_{3}$. Chromium oxide formation can be given by following reactions as mentioned in equations in 7 and $8^{59}$;

$$
\begin{gathered}
\mathrm{Cr}+1.50 \mathrm{O}_{2} \rightarrow \mathrm{CrO}_{3} \\
\left(\Delta G_{298 \mathrm{~K}}\right)=-273.46 \mathrm{KJ} \mathrm{mole}^{-1} \\
2 \mathrm{Cr}+1.50 \mathrm{O}_{2} \rightarrow \mathrm{Cr}_{2} \mathrm{O}_{3} \\
\left(\Delta G_{298 K}\right)=-1053.11 \mathrm{KJ} \mathrm{mole}^{-1}
\end{gathered}
$$

$\mathrm{Cr}_{3} \mathrm{C}_{2}$ oxidation can occur by following reaction as given in equation $9^{60}$;

$$
\mathrm{Cr}_{3} \mathrm{C}_{2}+3.25 \mathrm{O}_{2} \rightarrow 1.5 \mathrm{Cr}_{2} \mathrm{O}_{3}+2 \mathrm{CO}
$$

It has been also reported that the oxidation of $\mathrm{Cr}_{3} \mathrm{C}_{2}$ leads to the generation of secondary carbides like $\mathrm{Cr}_{7} \mathrm{C}_{3}$ and $\mathrm{Cr}_{23} \mathrm{C}_{6}{ }_{6}$. $\mathrm{Cr}_{23} \mathrm{C}_{6}$ phase was noted in the XRD spectra of worn surfaces. The hardness of $\mathrm{Cr}_{23} \mathrm{C}_{6}$ and $\mathrm{Cr}_{7} \mathrm{C}_{3}$ is lower than the $\mathrm{Cr}_{3} \mathrm{C}_{2}$, which can also cause increase in wear rates of $\mathrm{Cr}_{3} \mathrm{C}_{2}-25 \mathrm{NiCr}$ coating ${ }^{62}$. Nickel oxide $(\mathrm{NiO})$ and spinel oxide $\left(\mathrm{NiCr}_{2} \mathrm{O}_{4}\right)$ peaks were noted in XRD and XPS spectra of worn surfaces (Fig. 8e-h and Fig. 10g-h). Chemical reaction of oxidation of metallic $\mathrm{Ni}$ binder with $\mathrm{O}_{2}$ is given in equation $10^{63}$;

$$
\mathrm{Ni}+1 / 2 \mathrm{O}_{2} \rightarrow \mathrm{NiO}
$$

Spinel oxide phase $\mathrm{NiCr}_{2} \mathrm{O}_{4}$ was reported to be beneficial in reducing $\mathrm{COF}$ of $\mathrm{Cr}_{3} \mathrm{C}_{2}-\mathrm{NiCr}$ coating ${ }^{64}$. The formation of spinal phase $\mathrm{NiCr}_{2} \mathrm{O}_{4}$, could occur due to the chemical reactions between $\mathrm{Ni}$ (or $\mathrm{NiO}$ ) and $\mathrm{Cr}_{2} \mathrm{O} 3$, as expressed in equations 11 and $12^{60,65}$;

$$
\begin{gathered}
\mathrm{Cr}_{2} \mathrm{O}_{3}+\mathrm{Ni}+1 / 2 \mathrm{O}_{2} \rightarrow \mathrm{NiCr}_{2} \mathrm{O}_{4} \\
\mathrm{Cr}_{2} \mathrm{O}_{3}+\mathrm{Ni} \rightarrow \mathrm{NiCr}_{2} \mathrm{O}_{4}
\end{gathered}
$$

\subsection{Analyses of debris and worn abrasive paper}

SEM photographs of wear debris particle were shown in Fig. 11(a-f) for both the coatings. Expectedly, at lower load, the wear debris removal rate was lower as compared to that at higher load and for increase in load, relatively coarser wear debris was observed. $\mathrm{Cr}_{3} \mathrm{C}_{2}-25 \mathrm{NiCr}$ coating showed more amount of wear debris than WC-12Co coating, as revealed in Figs 11(d, e, f), which also supports higher wear rate shown by $\mathrm{Cr}_{3} \mathrm{C}_{2}-25 \mathrm{NiCr}$ coating than WC-12Co coating (Fig. 4). $\mathrm{SiC}, \mathrm{WC}, \mathrm{WO}_{2}, \mathrm{WO}_{3}, \mathrm{~W}_{3} \mathrm{O}_{8}, \mathrm{CoO}, \mathrm{Co}_{3} \mathrm{O}_{4}$ and $\mathrm{CoCo}_{2} \mathrm{O}_{4}$ phases were identified in wear debris of WC-Co coating while in XRD spectrum of wear debris of $\mathrm{Cr}_{3} \mathrm{C}_{2}-25 \mathrm{NiCr}$ coating, peaks of $\mathrm{Cr}_{3} \mathrm{C}_{2}, \mathrm{SiC}, \mathrm{Cr}_{2} \mathrm{O}_{3}, \mathrm{Ni}, \mathrm{NiO}, \mathrm{Cr}_{3} \mathrm{O}$, $\mathrm{CrO}_{3}, \mathrm{Cr}_{23} \mathrm{C}_{6}$ and spinel phase $\mathrm{NiCrO}_{4}$ were detected, as shown in Fig. 12(a-g). It was also observed that intensity of peaks and number of various oxide phases were influenced by sliding velocity and the load, due to difference in the frictional heat generation and associated rise in flash temperatures as discussed earlier. XRD analyses of wear debris particles, further supported the observation regarding varying degree of tribo-oxidation and tribofilm composition with change in abrasive wear test parameters. SiC peaks were attributed to fracture of $\mathrm{SiC}$ abrasive particles during wear. 

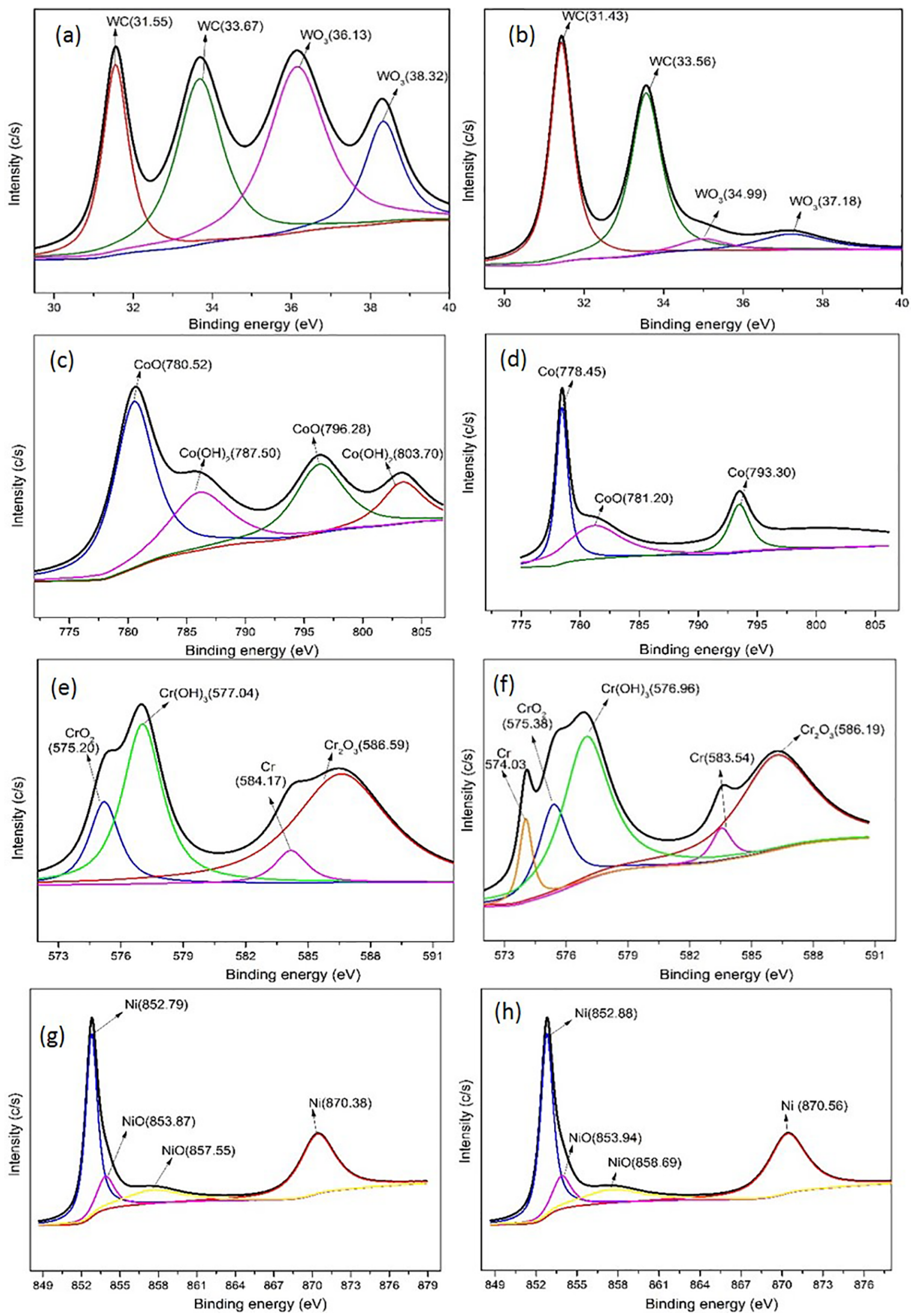

Figure 10. High resolution spectra of worn out surface elements of WC-12Co coating at $60 \mathrm{~N}$; W (a) $1.5 \mathrm{~m} \mathrm{~s}^{-1}$ (b) $0.25 \mathrm{~m} \mathrm{~s}^{-1}$ and Co (c) $1.5 \mathrm{~m} \mathrm{~s}^{-1}$ (d) $0.25 \mathrm{~m} \mathrm{~s}^{-1}$ and for $\mathrm{Cr}_{3} \mathrm{C}_{2}-25 \mathrm{NiCr}$ coating at $60 \mathrm{~N}$; $\mathrm{Cr}$ (e) $1.5 \mathrm{~m} \mathrm{~s}^{-1}$ (f) $0.25 \mathrm{~m} \mathrm{~s}^{-1}$ and Ni (g) $1.5 \mathrm{~m} \mathrm{~s}^{-1}$ (h) $0.25 \mathrm{~m} \mathrm{~s}^{-1}$ 

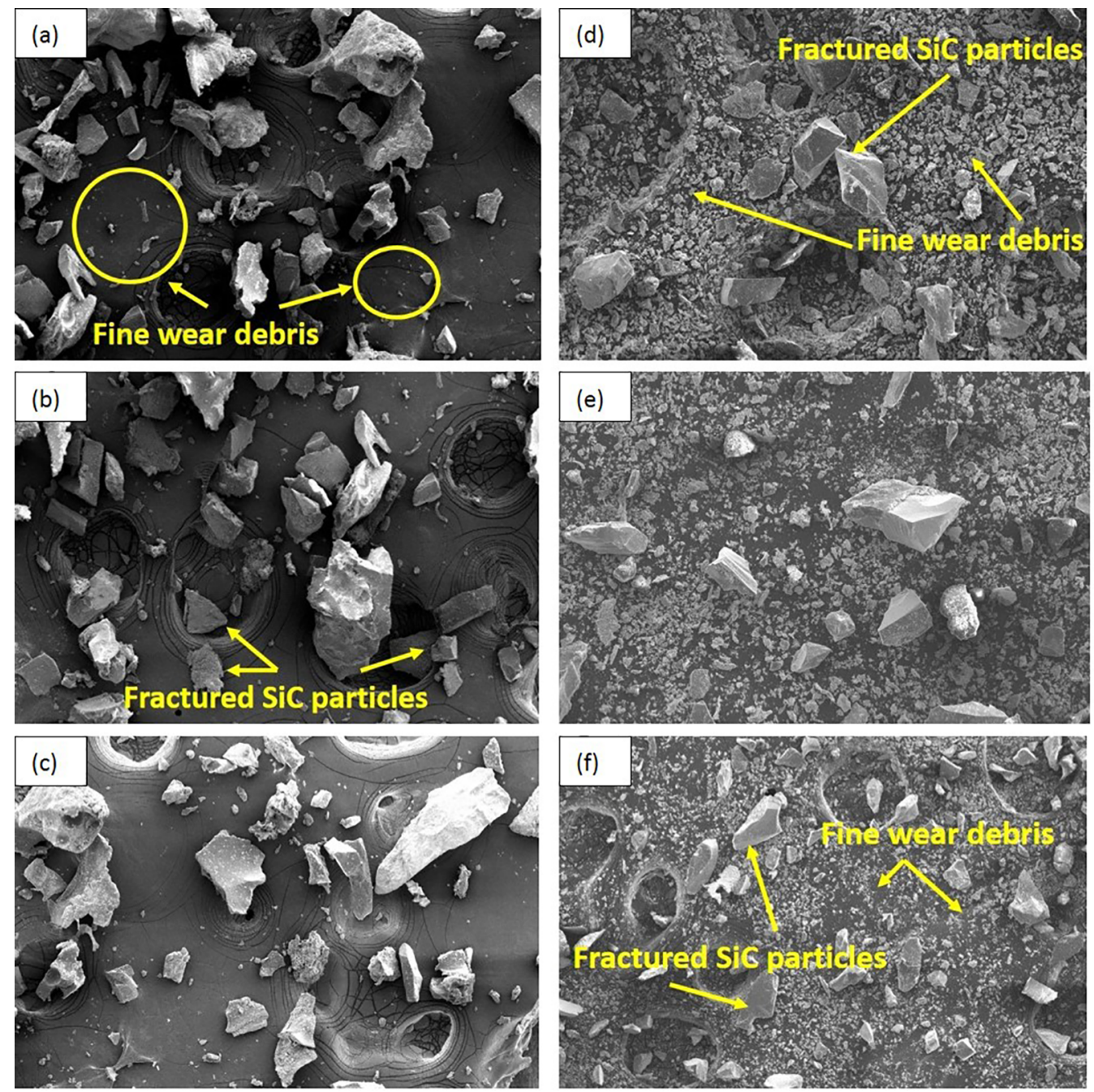

$50 \mu \mathrm{m}$

Figure 11. SEM micrographs of WC-12Co coating wear debris at $0.25 \mathrm{~m} \mathrm{~s}^{-1}$ (a) $60 \mathrm{~N}$, at $1.5 \mathrm{~m} \mathrm{~s}^{-1}$ (b) $60 \mathrm{~N}$, (c) $30 \mathrm{~N}$ and for $\mathrm{Cr}_{3} \mathrm{C}_{2}-25 \mathrm{NiCr}$ coatng at $0.25 \mathrm{~m} \mathrm{~s}^{-1}$ (d) $60 \mathrm{~N}$, at $1.5 \mathrm{~m} \mathrm{~s}^{-1}$ (e) $60 \mathrm{~N}$, (f) $30 \mathrm{~N}$

SEM photographs of worn SiC papers for different test conditions were shown in Fig. 13(a-h), for both the coatings. Fragmentation of $\mathrm{SiC}$ abrasive particles was relatively greater at higher loads $(45-60 \mathrm{~N})$ as compared to lower load (15-30 N). Low magnification SEM images as shown in Fig. 13(a \& e) reveals the greater extent of capping (covering of tip of abrasive particles with wear debris) and clogging (accumulation of wear debris in the spaces of abrasive particle) in case of $\mathrm{Cr}_{3} \mathrm{C}_{2}-25 \mathrm{NiCr}$ coating than that $\mathrm{WC}-12 \mathrm{Co}$ coating. Oxygen peaks revealed by EDS spectra of worn paper confirmed accumulation of wear debris on abrasive paper (Fig. 13i-j). The other features observed on worn papers were attrition of abrasive, edge rounding, fracture and fragmentation, removal (shelling) of abrasive particle, severity of these depends upon load.

\subsection{Wear and friction of coatings}

Friction and wear data for both the coatings with $50 \mu \mathrm{m}$ $\mathrm{SiC}$ abrasive particle size, obtained in present work, were compared with those obtained under similar test conditions with $150 \mu \mathrm{m} \mathrm{SiC}$ abrasive particle size ${ }^{19}$. Friction coefficients and wear rates were significantly affected by change in abrasive particle size. Both COF and wear showed decreasing trend with decrease in abrasive particle from 150 to $50 \mu \mathrm{m}$, although the extent of the decrease was influenced by load and sliding velocity. With $150 \mu \mathrm{m}$ particle size, the friction coefficients were $0.32-0.44$ and $0.27-0.38$ for WC-12 Co and $\mathrm{Cr}_{3} \mathrm{C}_{2}-25 \mathrm{NiCr}$ coatings, respectively. With increasing sliding speed $\left(0.25\right.$ to $\left.1.5 \mathrm{~m} \mathrm{~s}^{-1}\right)$, the reduction in COF was at the most $20 \%$ for WC-12 $\mathrm{Co}$ and $\mathrm{Cr}_{3} \mathrm{C}_{2}-25 \mathrm{NiCr}$ coatings, for both abrasive particle sizes. For both the particle sizes of 

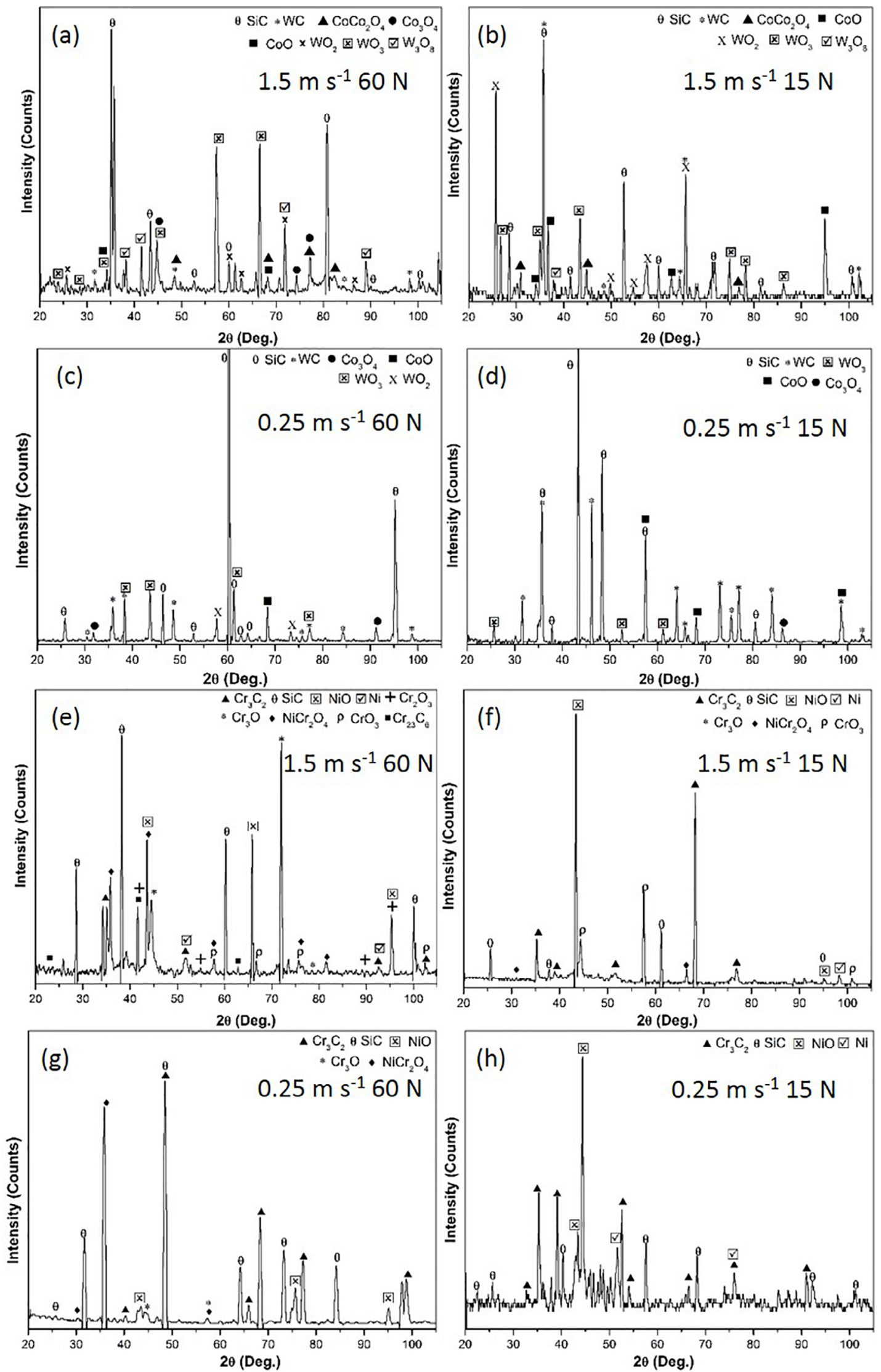

Figure 12. XRD spectra of wear debris of WC-12Co coating (a-d) and $\mathrm{Cr}_{3} \mathrm{C}_{2}-25 \mathrm{NiCr}$ coating (e-h); test conditions are as indicated in figures 

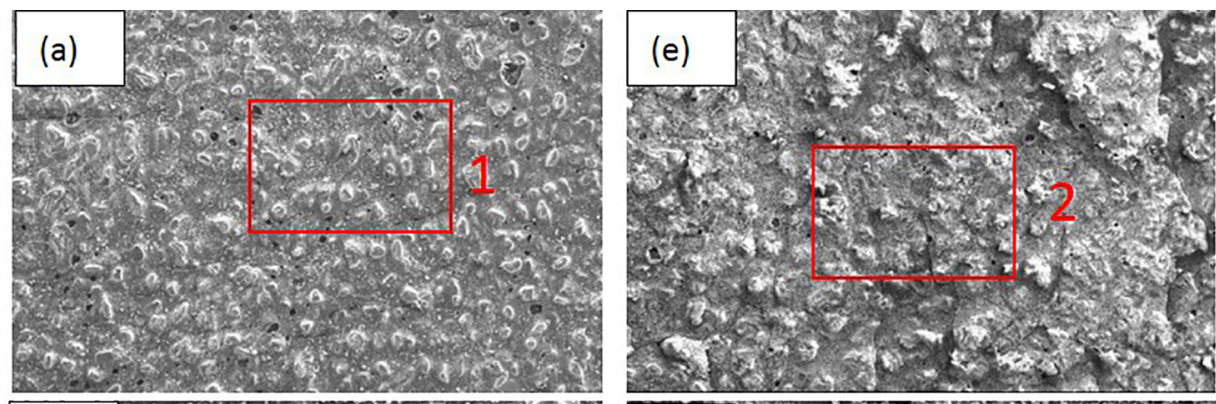

$500 \mu \mathrm{m}$
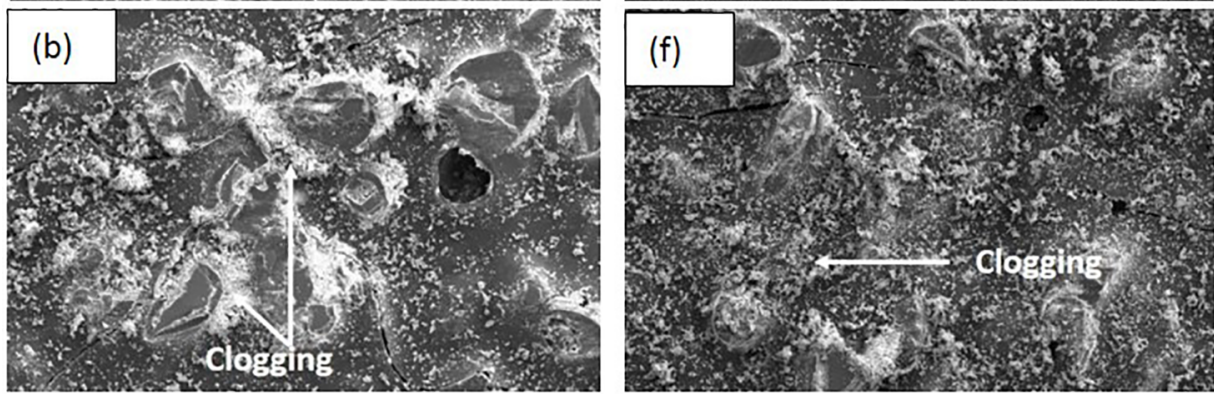

(for a \& e)
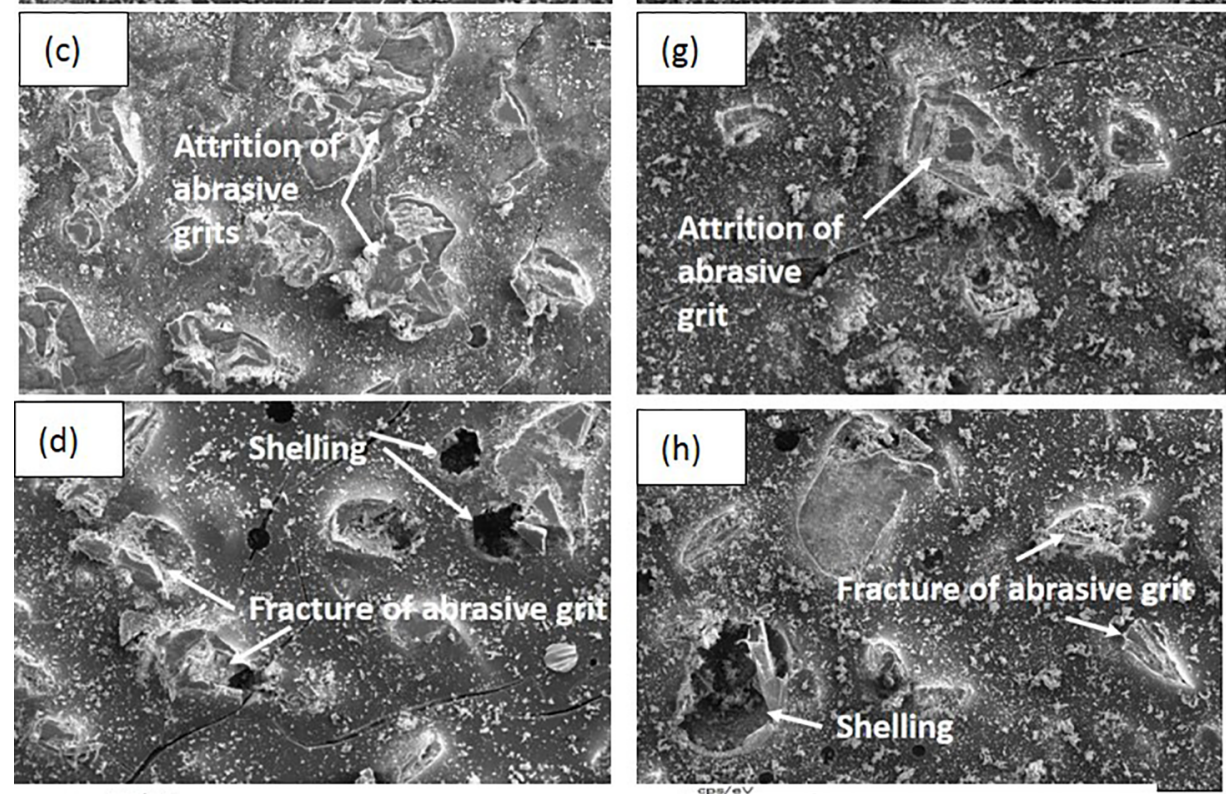

\section{$50 \mu \mathrm{m}$ \\ (for b-d \& f-h)}
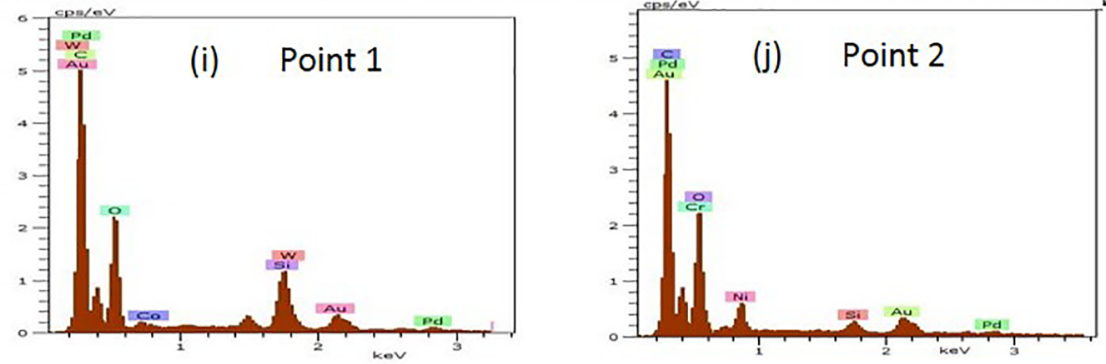

Figure 13. SEM micropgaphs of worn out $\mathrm{SiC}$ abrasive papers (a-d) WC-12Co coating and (e-h) $\mathrm{Cr}_{3} \mathrm{C}_{2}-25 \mathrm{NiCr}$ coating, (a,e) at $1.5 \mathrm{~m}$ $\mathrm{s}^{-1} 60 \mathrm{~N}$ with lower magnification, (b,f) at $1.5 \mathrm{~m} \mathrm{~s}^{-1} 60 \mathrm{~N}$ with higher magnification, (c,g) at $1.5 \mathrm{~m} \mathrm{~s}^{-1} 15 \mathrm{~N},(\mathrm{~d}, \mathrm{~h})$ at $0.25 \mathrm{~m} \mathrm{~s}^{-1} 60 \mathrm{~N}$. EDS analysis of selected points (i-j)

50 and $150 \mu \mathrm{m}$, the COF displayed increasing trend when the load was increased from 15 to $60 \mathrm{~N}$. The maximum rise in $\mathrm{COF}$ was $14 \%$ and $31 \%$ for WC-12 Co coating for 150 and $50 \mu \mathrm{m}$ particle size, respectively whereas respective values for $\mathrm{Cr}_{3} \mathrm{C}_{2}-25 \mathrm{NiCr}$ coating were $17 \%$ and $34 \%$. Both coatings showed lower friction coefficients with 50 $\mu \mathrm{m}$ abrasive particle size as compared to that with $150 \mu \mathrm{m}$ particle, the magnitude of which was governed by load and 
sliding speed. The maximum decrease in COF of around 20$26 \%$ was noted at lower load of $15 \mathrm{~N}$, for both the coatings over sliding velocities in the range of $0.25-1.5 \mathrm{~m} \mathrm{~s}^{-1}$. At higher loads $(45-60 \mathrm{~N})$, the decrease was $10-20 \%$ for both coatings, depending on sliding speed and load. Abrasive wear rate showed diminishing trend for increasing sliding speed while with increasing load abrasive wear rate increased for both coatings. Abrasive wear rates were in the range of $2.61 \times 10^{-4}-14.2 \times 10^{-4} \mathrm{~mm}^{3} \mathrm{~m}^{-1}$ and $11 \times 10^{-4}-35.36 \times 10^{-4}$ $\mathrm{mm}^{3} \mathrm{~m}^{-1}$ with $150 \mu \mathrm{m}$ particle size in case of WC-12 Co and $\mathrm{Cr}_{3} \mathrm{C}_{2}-25 \mathrm{NiCr}$ coatings, respectively. With reduction in abrasive particle size to $50 \mu \mathrm{m}$, wear rates reduced by around two times and more than three times for WC-12 Co and $\mathrm{Cr}_{3}$ $\mathrm{C}_{2}-25 \mathrm{NiCr}$ coatings, respectively. Wear rate increased for increase in load $(15 \mathrm{~N}-60 \mathrm{~N})$ which was around 2.5-3 and 2.6-3.4 times for both coatings, for abrasive particle size of $150 \mu \mathrm{m}$ and $50 \mu \mathrm{m}$, respectively.

The frictional behaviour of WC-12 Co and $\mathrm{Cr}_{3} \mathrm{C}_{2}-25$ $\mathrm{NiCr}$ coating can be explained on the basis of contribution of abrasion and adhesion components of friction, tribo-oxidation and mechanical and oxidative wear, with change in wear test conditions. The reduction in $\mathrm{COF}$ and wear rate for increase in sliding velocity for both the coatings can be attributed to tribo oxide films. Tribo-films have lower shear strength and protects the worn surface by acting as solid lubricant, as discussed earlier. However, change in composition of oxides and the extent of tribo- oxidation altered friction response of both the coatings. In case of WC-12Co coating, at lowest velocity, the intensity of peak of oxides $\mathrm{W}$ and Co was relatively weak as compared to those at highest velocity, as revealed by phase analyses of worn surface. Similarly, in case of $\mathrm{Cr}_{3} \mathrm{C}_{2}-25 \mathrm{NiCr}$ coating, strong peaks of oxide of $\mathrm{Cr}$ and $\mathrm{Ni}$ were noted at highest sliding speed, indicating an increase in severity of oxidative wear, which is also supported by increased flash temperatures with rise in sliding velocity, as discussed earlier. Relatively lower COF exhibited by $\mathrm{Cr}_{3} \mathrm{C}_{2}-25 \mathrm{NiCr}$ coating can be attributed to $\mathrm{Cr}_{2} \mathrm{O}_{3}$ film with greater thermodynamic stability and spinel phase $\mathrm{NiCr}_{2} \mathrm{O}_{4}$, which help in reduction of COF.

Adhesion and ploughing are two important components which contributes to friction between two surfaces. The adhesion between two surfaces is influenced by real area of contact whereas angle of attack posed by asperities decide ploughing component. With decrease in abrasive size, capping and clogging of abrasive paper result in agglomeration of wear debris particle on paper and adhesion mechanism becomes dominant and for increased abrasive particle size, abrasion mechanism become prevalent ${ }^{43,45,50}$. The contribution of abrasion and adhesion to friction coefficient is also governed by ratio of abrasive hardness to surface hardness $(\mathrm{Ha} / \mathrm{Hs})$ during abrasive wear, apart from the contact pressure and the deterioration of abrasive particles. The degradation of abrasives can modify attack angle and material removal rate and generation of wear debris. With higher $\mathrm{Ha} / \mathrm{Hs}$ ratio, a minimum in friction coefficient was observed for abrasive particle size of $35 \mu \mathrm{m}$; adhesion became prominent below this particle size and abrasion component was increased above this particle size ${ }^{44}$. In cermets with high volume fraction of carbides, contribution to total material removal rate arises from hard phase (carbide) and soft phase (binder). Considering $\mathrm{Ha} / \mathrm{Hc}$ ratio (abrasive hardness to carbide hardness), it can be observed that silicon carbide particle has comparable hardness to tungsten carbide in case of WC-12Co coating, whereas $\mathrm{Ha} / \mathrm{Hc}$ ratio in case of $\mathrm{Cr}_{3} \mathrm{C}_{2}-25 \mathrm{NiCr}$ coating was more than 1.3. However, in two phase materials like cermets, the material removal rate from carbides is also augmented by removal of binder i.e. bodily removal and carbide pull out, propensity of which increases with an increase in load, as pointed earlier. Thus, the wear debris generation rate in these coating is strongly influenced by microstructural features like difference in carbide size, binder content and $\mathrm{Ha} / \mathrm{Hc}$ and varying fracture toughness ${ }^{11,66}$. The other aspect which needs attention and which has not been addressed by previous researchers is tribo oxidation effects with change in load, sliding velocity abrasive size. In the present work, friction coefficient increased when the load was increased from $15 \mathrm{~N}$ to $45 \mathrm{~N}$, which can be attributed to combined effect of adhesion and abrasion. SEM image of wear debris particle, as shown in Fig. 10, demonstrate the differences in amount and size of wear debris particles for variation in load and sliding speed, for both coatings. It is expected that during abrasive wear, abrasion predominantly contributes to friction between two surfaces.

With relatively finer abrasive particles, with increase in load, contribution of both adhesion and abrasion components increased, which is supported by SEM images of worn abrasive papers, as shown in Fig. 13. Similarly, with increase in load, due to rise in flash temperature (Fig. 7) tribo oxidation led to formation of tribo films, which also decreases real contact area and helps in reduction in $\mathrm{COF}$, as discussed in section 3.3. Thus, reduction in friction coefficient at $45 \mathrm{~N}$ load can be justified as following; firstly, by balance of abrasion and adhesion to friction coefficient, secondly the rate of formation of tribo film and its removal reaching to an equilibrium and thirdly, because of increased load, fragmentation and fracture of abrasive particles increases and fractured particles have reduced cutting efficiency due to decrease in attack angle. Further increase in COF to $60 \mathrm{~N}$ was due to delamination of agglomerated wear debris on worn abrasive paper which also acted as a third body and contributes to abrasion and easy removal of tribo film due to enhanced contribution of mechanical wear, which has resulted in increased COF at higher load of $60 \mathrm{~N}$ for both coatings.

The correlation between flash temperature, abrasive wear rate and $\mathrm{COF}$ as a function of sliding velocity is shown in Fig. 14(a-b), for WC-12 Co and $\mathrm{Cr}_{3} \mathrm{C}_{2}-25 \mathrm{NiCr}$ coatings. The reduction in wear rate for increase in velocity was observed and increased flash temperatures were noted for increase in 
sliding speed. However, no consistent correlation between wear rate and COF of coatings was observed. The friction and wear behaviour of any material depends upon chemical, physical, and mechanical interaction between two surfaces and with the environment. Wear and friction are therefore regarded not as intrinsic properties but as system properties. The decrease in abrasive wear rate of carbide based coatings for increase in sliding speed and rise in COF for rise in load was also observed previously ${ }^{37,67-69}$ whereas contradictory observations have also been reported ${ }^{35}$.

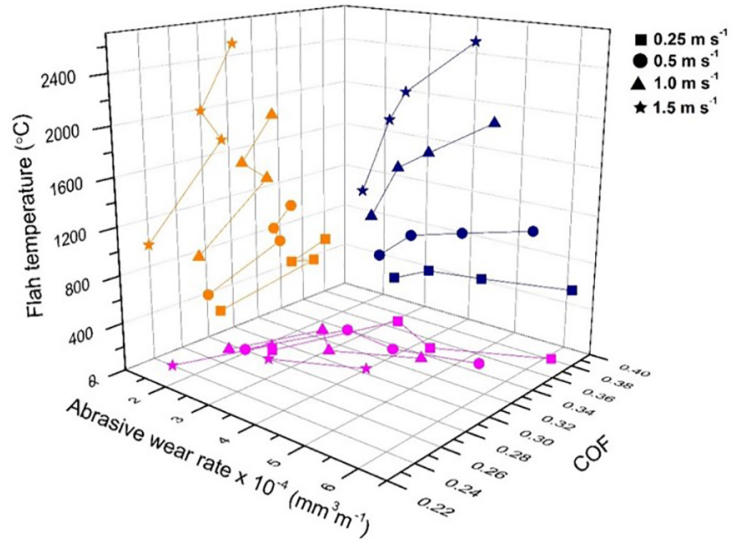

(a)

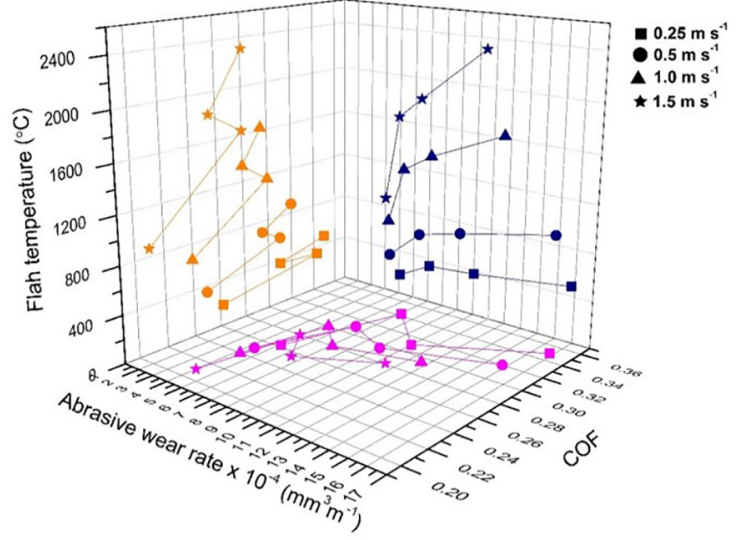

(b)

Figure 14. Correlation in abrasive wear rate, $\mathrm{COF}$ and flash temperature (a) WC-12Co coating (b) $\mathrm{Cr}_{3} \mathrm{C}_{2}-25 \mathrm{NiCr}$ coating

The variation in COF and wear rate of coatings with decreasing abrasive particle size was also associated with the change in their attack angle. In generally, abrasive particle attack angle decreases with decreasing particle size leading to lower wear rates ${ }^{43}$. A change in abrasive particle attack angle also results in the transition in material removal mechanisms which effectuate abrasive particle size effect on wear and friction response. Abrasive particle fragmentation was more predominant with lower particle size and deterioration abrasive particle was more severe with increasing load while coarser abrasive particles show less fragmentation due to their partial participation in abrasion process ${ }^{45}$. Finer $\mathrm{SiC}$ abrasive particles due to fragmentation can aid in easily removal of binder by undermining process, which resulted binder rich tribo-layer formation, as confirmed by phase analysis of worn surfaces in the present work. With coarser abrasive, predominant material removal mechanisms were plastic grooving of binder phase, carbide pullout, carbide fracture, delamination cracking and fracture of splats ${ }^{19}$. With finer abrasive particles the mechanism showed transition from plastic deformation to fracture with an increase in load as observed in the present work. The worn surfaces were covered by tribo oxide layer which was up to $60 \%$ with coarser abrasive particles 19 while tribo oxides covering worn surface was around $40 \%$ with finer abrasive particle size due to relatively lower rise in flash temperatures, as noted in present investigation. The combined effect of adhesion and abrasion to friction, variation in tribo oxidation, change in wear mechanisms and varying contribution of oxidative and mechanical wear as influenced by load and sliding velocity, could explain the differences in tribological behaviour of coatings.

\section{Conclusions}

The abrasive experiments were carried using $50 \mu \mathrm{m}$ $\mathrm{SiC}$ abrasive particles with varying load and sliding speeds. The detailed study of abraded surfaces, wear debris, worn abrasive papers has contributed in understanding of wear mechanisms, tribo oxidation effects and phase composition of tribo chemical reaction films. The conclusions of present work can be summarized as follows.

1. The better wear resistance of WC-12 Co coating was attributed to its relatively higher fracture toughness than $\mathrm{Cr}_{3} \mathrm{C}_{2}-25 \mathrm{NiCr}$ coating. The tribo mechanisms exhibited transition from plastic grooving to fracture with increasing load.

2. The lower friction coefficient of $\mathrm{Cr}_{3} \mathrm{C}_{2}-25 \mathrm{NiCr}$ coating was due to tribo oxide films of $\mathrm{Cr}_{2} \mathrm{O}_{3}$ and $\mathrm{NiCr}_{2} \mathrm{O}_{4}$.

3. The difference in magnitude of decrease in wear rate and COF of coatings with reduction in sliding speed was attributed to varying degree of tribo-oxidation, stability and phase composition of tribo-chemical reaction film.

4. The change in COF with increase in load for both the coatings was due to combined effect of adhesion, abrasion and tribo oxidation.

\section{Acknowledgement}

The authors are grateful to the Director, VNIT for providing necessary facilities in carrying out this investigation and TEQIP II grant, F. NO.16- 6/2015-TS-VII, GOI, MHRD India 
for financial assistance. The authors are also thankful to Mr. Umesh Shende for their help in abrasive wear experimentation.

\section{References}

1. Wood RJK. Tribology of thermal sprayed WC-Co coatings. International Journal of Refractory Metals and Hard Materials. 2010;28(1):82-94.

2. Picas JA, Forn A, Matthäus G. HVOF coatings as an alternative to hard chrome for pistons and valves. Wear. 2006;261(2006):477-484.

3. Sapate SG, Roy M. Solid particle erosion of thermal sprayed coatings. In: Roy M, Davim JP, eds. Thermal Sprayed Coatings and their Tribological Performances. Hershey: IGI Global Publications; 2015. p. 193-226.

4. Gong T, Yao P, Zuo X, Zhang Z, Xiao Y, Zhao L, et al. Influence of WC carbide particle size on the microstructure and abrasive wear behavior of WC-10Co-4Cr coatings for aircraft landing gear. Wear. 2016;362-363(2016):135-145.

5. Thakare MR, Wharton JA, Wood RJK, Menger C. Effect of abrasive particle size and the influence of microstructure on the wear mechanisms in wear-resistant materials. Wear. 2012;276-277:16-28.

6. Roy M, Rao CVS, Rao DS, Sundararajan G. Abrasive wear behaviour of detonation sprayed WC-Co coatings on mild steel. Surface Engineering. 1999;15(2):129-136.

7. Kembaiyan KT, Keshavan K. Combating severe fluid erosion and corrosion of drill bits using thermal spray coatings. Wear. 1995;186-187(Pt 2):487-492

8. Sharma S. Parametric study of abrasive wear of Co-CrC based flame sprayed coatings by Response Surface Methodology. Tribology International. 2014;75:39-50.

9. Vashishtha N, Khatirkar RK, Sapate SG. Tribological behaviour of HVOF sprayed WC-12Co, WC-10Co-4Cr and $\mathrm{Cr}_{3} \mathrm{C}_{2}-25 \mathrm{NiCr}$ coatings. Tribology International. 2017;105:55-68.

10. Babu PS, Basu B, Sundararajan G. Abrasive wear behavior of detonation sprayed WC-12Co coatings: Influence of decarburization and abrasive characteristics. Wear. 2010;268(11-12):1387-1399.

11. Vashishtha N, Sapate SG, Bagde P, Rathod AB. Effect of heat treatment on friction and abrasive wear behaviour of WC$12 \mathrm{Co}$ and $\mathrm{Cr}_{3} \mathrm{C}_{2}-25 \mathrm{NiCr}$ coatings. Tribology International. 2018;118:381-399.

12. Poirier D, Legoux JG, Lima RS. Engineering HVOF-Sprayed $\mathrm{Cr}_{3} \mathrm{C}_{2}$-NiCr Coatings: The Effect of Particle Morphology and Spraying Parameters on the Microstructure, Properties, and High Temperature Wear Performance. Journal of Thermal Spray Technology. 2013;22(2-3):280-289.

13. Stewart DA, Shipway PH, McCartney DG. Influence of heat treatment on the abrasive wear behaviour of HVOF sprayed WC-Co coatings. Surface and Coatings Technology. 1998;105(1-2):13-24.

14. Bolelli G, Berger LM, Bonetti M, Lusvarghi L. Comparative study of the dry sliding wear behaviour of HVOF-sprayed $\mathrm{WC}-(\mathrm{W}, \mathrm{Cr})_{2} \mathrm{C}-\mathrm{Ni}$ and $\mathrm{WC}-\mathrm{CoCr}$ hardmetal coatings. Wear. 2014;309(1-2):96-111.
15. Geng Z, Hou S, Shi G, Duan D, Li S. Tribological behaviour at various temperatures of WC-Co coatings prepared using different thermal spraying techniques. Tribology International. 2016;104:36-44.

16. Jacobs L, Hyland MM, De Bonte M. Study of the influence of microstructural properties on the sliding-wear behavior of HVOF and HVAF sprayed WC-cermet coatings. Journal of Thermal Spray Technology. 1999;8(1):125-132.

17. Murthy JKN, Venkataraman B. Abrasive wear behaviour of WC-CoCr and $\mathrm{Cr}_{3} \mathrm{C}_{2}-20(\mathrm{NiCr})$ deposited by HVOF and detonation spray processes. Surface and Coatings Technology. 2006;200(8):2642-2652.

18. Bolelli G, Berger LM, Börner T, Koivuluoto H, Lusvarghi L, Lyphout C, et al. Tribology of HVOF- and HVAF-sprayed WC-10Co4Cr hardmetal coatings: A comparative assessment. Surface and Coatings Technology. 2015;265:125-144.

19. Vashishtha N, Sapate SG. Abrasive wear maps for High Velocity Oxy Fuel (HVOF) sprayed WC-12 Co and $\mathrm{Cr}_{3} \mathrm{C}_{2}-25 \mathrm{NiCr}$ coatings. Tribology International. 2017;114:290-305.

20. Sudaprasert T, Shipway PH, McCartney DG. Sliding wear behaviour of HVOF sprayed WC-Co coatings deposited with both gas fuelled and liquid fuelled systems. Wear. 2003;255(7-12):943-949.

21. Guilemany JM, Miguel JM, Vizcaino S, Lorenzana C, Delgado J, Sánchez J. Role of heat treatments in the improvement of the sliding wear properties of $\mathrm{Cr}_{3} \mathrm{C}_{2}-\mathrm{NiCr}$ coatings. Surface and Coatings Technology. 2002;157(2-3):207-213.

22. Chivavibul P, Watanabe M, Kuroda S, Shinoda K. Effects of carbide size and Co content on the microstructure and mechanical properties of HVOF-sprayed WC-Co coatings. Surface and Coatings Technology. 2007;202(3):509-521.

23. Stewart DA, Shipway PH, McCartney DG. Abrasive wear behaviour of conventional and nanocomposite HVOF-sprayed WC-Co coatings. Wear. 1999;225-229(Pt 2):789-798.

24. Usmani S, Sampath S, Houck DL, Lee D. Effect of Carbide Grain Size on the Sliding and Abrasive Wear Behavior of Thermally Sprayed WC-Co Coatings. Tribology Transactions. 1997;40(3):470-478.

25. Ma N, Guo L, Cheng ZX, Wu HT, Ye FX, Zhang KK. Improvement on mechanical properties and wear resistance of HVOF sprayed WC-12Co coatings by optimizing feedstock structure. Applied Surface Science. 2014;320:364-371.

26. Murugan K, Ragupathy A, Balasubramanian V, Sridhar K. Optimizing HVOF spray process parameters to attain minimum porosity and maximum hardness in $\mathrm{WC}-10 \mathrm{Co}-4 \mathrm{Cr}$ coatings. Surface and Coatings Technology. 2014;247:90-102.

27. Picas JA, Punset M, Baile MT, Martín E, Forn A. Effect of oxygen/fuel ratio on the in-flight particle parameters and properties of HVOF WC-CoCr coatings. Surface and Coatings Technology. 2011;205(Suppl. 2):S364-S368.

28. Wesmann JAR, Espallargas N. Effect of atmosphere, temperature and carbide size on the sliding friction of self-mated HVOF WC-CoCr contacts. Tribology International. 2016;101:301-313.

29. Yang QQ, Senda T, Ohmori A. Effect of carbide grain size on microstructure and sliding wear behavior of HVOF-sprayed WC-12\% Co coatings. Wear. 2003;254(1-2):23-34. 
30. Roy M, Pauschitz A, Polak R, Franek F. Comparative evaluation of ambient temperature friction behaviour of thermal sprayed $\mathrm{Cr}_{3} \mathrm{C}_{2}-25$ (Ni20Cr) coatings with conventional and nano-crystalline grains. Tribology International. 2006;39(1):29-38.

31. Wood RJK, Herd S, Thakare MR. A critical review of tribocorrosion of cemented and thermal sprayed tungsten carbide. Tribology International. 2018;119:491-509.

32. Gee MG, Gant A, Roebuck B. Wear mechanisms in abrasion and erosion of $\mathrm{WC} / \mathrm{Co}$ and related hardmetals. Wear. 2007;263(1-6):137-148.

33. Basse JL. Binder extrusion in sliding wear of WC-Co alloys. Wear. 1985;105(3):247-256.

34. Yang Q, Senda T, Hirose A. Sliding wear behaviour of WC$12 \%$ Co coatings at elevated temperatures. Surface and Coatings Technology. 2006;200(14-15):4208-4212.

35. Engqvist $\mathrm{H}$, Högberg H, Botton GA, Ederyd S, Axén N. Tribofilm formation on cemented carbides in dry sliding conformal contact. Wear. 2000;239(2):219-228.

36. Mohanty M, Smith RW, De Bonte M, Celis JP, Lugscheider E. Sliding wear behavior of thermally sprayed $75 / 25 \mathrm{Cr}_{3} \mathrm{C}_{2} / \mathrm{NiCr}$ wear resistant Coatings. Wear. 1996;198(1-2):251-266.

37. Edrisy A, Perry T, Cheng YT, Alpas AT. Wear of thermally spray deposited low carbon steel coatings on aluminum alloys. Wear. 2001;251(1-12):1023-1033.

38. Zhang C, Song J, Jiang L, Gao J, Liang G, Lei C, et al. Fabrication and tribological properties of $\mathrm{WC}_{-} \mathrm{TiB}_{2}$ composite cutting tool materials under dry sliding condition. Tribology International. 2017;109:97-103.

39. Vashishtha N, Sapate SG, Gahlot JS, Pranay Bagde P. Effect of Tribo-Oxidation on Friction and Wear Behaviour of HVOF Sprayed WC-10Co-4Cr Coating. Tribology Letters. 2018;66:56.

40. Hutchings IM. Tribology: Friction and Wear of Engineering Materials. Oxford: Butterworth-Heinemann; 1992.

41. Singh K, Khatirkar RK, Sapate SG. Microstructure evolution and abrasive wear behaviour of D2 steel. Wear. 2015;328-329:206-216.

42. Sevim I, Eryurek IB. Effect of abrasive particle size on wear resistance in steels. Materials \& Design. 2006;27(3):173-181.

43. Jourani A, Bouvier S. Friction and Wear Mechanisms of 316L Stainless Steel in Dry Sliding Contact: Effect of Abrasive Particle Size. Tribology Transactions. 2015;58(1):131-139.

44. Trevisiol C, Jourani A, Bouvier S. Effect of hardness, microstructure, normal load and abrasive size on friction and on wear behaviour of 35NCD16 steel. Wear. 2017;388-389:101-111.

45. Narayanaswamy B, Hodgson P, Beladi H. Effect of particle characteristics on the two-body abrasive wear behaviour of a pearlitic steel. Wear. 2016;354-355:41-52.

46. Pirso J, Viljus M, Letunovitš S. Friction and dry sliding wear behaviour of cermets. Wear. 2006;260(6-7) 815-824.

47. Qi X, Eigen N, Aust E, Gärtner F, Klassen T, Bormann R. Twobody abrasive wear of nano- and microcrystalline TiC-Ni-based thermal spray coatings. Surface and Coatings Technology. 2006;200(16-17):5037-5047.

48. Rajinikanth V, Venkateswarlu K. An investigation of sliding wear behaviour of WC-Co coating. Tribology International. 2011;44(12):1711-1719.
49. Nicholls JR, Wellman RG. Oxidative Wear. In: Bruce RW, ed. Handbook of Lubrication and Tribology, Volume II: Theory and Design. $2^{\text {nd }}$ ed. Boca Raton: CRC Press; 2012.

50. Bagde P, Sapate SG, Khatirkar RK, Vashishtha N. Friction and abrasive wear behaviour of $\mathrm{Al}_{2} \mathrm{O}_{3}-13 \mathrm{TiO}_{2}$ and $\mathrm{Al}_{2} \mathrm{O}_{3}-13 \mathrm{TiO}_{2}-\mathrm{Ni}$ Graphite coatings. Tribology International. 2018;121:353-372.

51. LiuY,ErdemirA,Meletis EI.Astudy of the wearmechanism of diamondlike carbonfilms. Surface and Coatings Technology. 1996;82(1-2):48-56.

52. So H, Yu DS, Chuang CY. Formation and wear mechanisms of tribo-oxides and the regime of oxidational wear of steel. Wear. 2002;253(9-10):1004-1015.

53. Voitovich VB, Sverdel VV, Voitovich RF, Golovko EI. Oxidation of WC-Co, WC-Ni and WC-Co-Ni hard metals in the temperature range $500-800^{\circ} \mathrm{C}$. International Journal of Refractory Metals and Hard Materials. 1996;14(4):289-295.

54. Geng Z, Li S, Duan DL, Liu Y. Wear behaviour of WC-Co HVOF coatings at different temperatures in air and argon. Wear. 2015;330-331:348-353.

55. Magnéli A. Structures of the ReO3-type with recurrent dislocations of atoms: 'homologous series' of molybdenum and tungsten oxides. Acta Crystallographica. 1953;6(6):495-500.

56. Wesmann JAR, Kuroda S, Espallargas N. The role of Oxide Tribofilms on Friction and Wear of Different Thermally Sprayed WC-CoCr. Journal of Thermal Spray Technology. 2017;26(3):492-502.

57. Chen LY, Yi DQ, Wang B, Liu HQ, Wu CP. Mechanism of the early stages of oxidation of WC-Co cemented carbides. Corrosion Science. 2016;103:75-87.

58. Petitto SC, Marsh EM, Carson GA, Langell MA. Cobalt oxide surface chemistry: The interaction of $\mathrm{CoO}\left(\begin{array}{lll}1 & 0 & 0\end{array}\right), \mathrm{Co}_{3} \mathrm{O}_{4}\left(\begin{array}{lll}1 & 1 & 0\end{array}\right)$, and $\mathrm{Co}_{3} \mathrm{O}_{4}\left(\begin{array}{lll}1 & 1 & 1\end{array}\right)$ with oxygen and water. Journal of Molecular Catalysis A: Chemical. 2008;281(1-2):49-58.

59. Tedmon CS Jr. The Effect of Oxide Volatization on the Oxidation Kinetics of $\mathrm{Cr}$ and Fe-Cr Alloys. Journal of the Electrochemical Society. 1966;113(8):766-768.

60. Ding Y, Hussain T, McCartney DG. High temperature oxidation of HVOF thermally sprayed $\mathrm{NiCr}-\mathrm{Cr}_{3} \mathrm{C}_{2}$ coatings: microstructure and kinetics. Journal of Materials Science. 2000;50(20):6808-6821.

61. Kamal S, Jayaganthan R, Prakash S. High temperature oxidation studies of detonation-gun-sprayed $\mathrm{Cr}_{3} \mathrm{C}_{2}$ - $\mathrm{NiCr}$ coating on $\mathrm{Fe}$ - and $\mathrm{Ni}$-based superalloys in air under cyclic conditions at $900^{\circ} \mathrm{C}$. Journal of Alloys and Compounds. 2009;472(1-2):378-389.

62. Chattopadhyay R. Surface Wear: Analysis, Treatment, and Prevention. Materials Park: ASM International; 2001.

63. Sidhu BS, Prakash S. Nickel chromium plasma sprayed coatings: A way to enhance degradation resistance of boiler tube steels in boiler environment. Journal of Thermal Spray Technology. 2006;15(1):131-140.

64. Tkachenko YG, Klimenko VN, Gorbatov IN, Maslyuk VA, Yurchenko DZ. Friction and wear of chromium carbide-nickel alloys at temperatures of $20-1000^{\circ} \mathrm{C}$. Soviet Powder Metallurgy and Metal Ceramics. 1978;17(11):864-867.

65. Calvarin G, Molins R, Huntz AM. Oxidation Mechanisms of $\mathrm{Ni}-20 \mathrm{Cr}$ Foils and Its Relation to the Oxide Scale Microstructure. Oxidation of Metals. 2000;53(1-2):25-48. 
66. Sapate SG, Rama Rao AV. Effect of material hardness on erosive wear behaviour of some weld deposited alloys. Materials and Manufacturing Processes. 2002;17(2):187-198.

67. Liu YL, Cheng J, Yin B, Zhu SG, Qiao ZH, Yang J. Study of the tribological behaviors and wear mechanisms of WC-Co and WC-Fe3 $\mathrm{Al}$ hard materials under dry sliding condition. Tribology International. 2017;109:19-25.
68. Gunes I. Effect of sliding speed on the frictional behavior and wear performance of borided and plasma-nitrided $\mathrm{W}_{9} \mathrm{Mo}_{3} \mathrm{Cr}_{4} \mathrm{~V}$ high-speed steel. Materials and Technology. 2015;49(1):111-116.

69. Vashishtha N, Sapate SG, Sahariah BJ, Bagde P. Microstructural characterization and wear behaviour of High Velocity Oxy Fuel sprayed $\mathrm{Cr}_{3} \mathrm{C}_{2}-25 \mathrm{NiCr}$ coating. Materials Today: Proceedings. 2018;5(9 Pt 3):17686-17693. 